\title{
Orígenes, trayectoria e identidades ideológicas de la milicia republicana, 1932-1936*
}

\author{
Origins, trayectory and ideologicals identities of republican militia, \\ 1932-1936
}

Luis Corvalán Marquez ${ }^{* *}$

Resumen: El artículo, distanciándose de las tesis que la historiografía ha postulado sobre el tema, estudia los orígenes, la trayectoria y las identidades ideológicas de la Milicia Republicana planteando que esta no constituía una organización homogénea y que, junto con perseguir objetivos compartidos entre todos sus miembros, habían otros respecto de los cuales es posible detectar diferencias, lo cual se reflejaría en los discursos de la entidad

Palabras clave: heterogeneidad, ideología, nacionalismo, antimilitarismo, oligarquía, liberalismo

\begin{abstract}
The article -far of the thesis defended for the historiography- study the origins, trajectory and the ideological identities of the Republicans Militia, standing that this organization was not homogeny and that, persuing certain objectives shared for all its members, existed anothers in which is possible to detect differences, what is reflected in their discourses.
\end{abstract}

Keywords: heterogeneousness, ideology, nationalism, antimilitarism

Recibido: 7 febrero 2016

Aceptado: 12 mayo 2016

La Milicia Republicana no ha sido muy estudiada por la historiografía nacional. Entre quienes lo han hecho figura Verónica Valdivia. Esta, en su texto, Las Milicias Republicanas. Los civiles en armas, 1932-1936, argumenta la tesis según la cual la Milicia "no sólo fue una respuesta a los socialistas del 4 de junio sino que además (representó) un

\footnotetext{
* Este artículo forma parte del proyecto "De Jorge González von Marées a Jaime Guzmán: para una historia del pensamiento antidemocrático chileno.1931-1989." Dirección de Investigaciones de la Universidad de Valparaíso (DIUV), DIUV-Reg. n 19-2011

** Chileno, Dr. en estudios Americanos, académico de la Universidad de Valparaíso, Chile, lcorvala@hotmail.com
} 
intento de revitalizar al pueblo chileno con valores y símbolos nacionales y patriotas que lo fortalecerían, devolviéndole su espíritu y civismo,"1 lo cual implicaría que la Milicia poseía un proyecto político, a lo menos implícito (que, según esta autora, sería el de la "revitalización nacional").

Gonzalo Vial, desde una óptica conservadora, rechaza expresamente este planteamiento y, más bien, hace fe de lo que la Milicia Republicana dijera de sí misma. Esto es, que constituía "una reacción (armada) contra la amenaza constante de la revuelta y del desorden", sin calificar "al gobierno que el país se diera." En este marco, lo único que a la Milicia le habría interesado sería la defensa del orden institucional, entonces amenazado por el intervencionismo militar y por otros actores revolucionarios o subversivos. De allí que en sus filas -agrega Vial- se aceptaban "todas las ideologías políticas, todos los credos y todas las capas sociales". ${ }^{2}$

Felipe Portales, por su parte, en su libro, Los mitos de la democracia chilena, no cree en la eventual neutralidad de la Milicia Republicana y postula que "la orientación principal subyacente en (ella) era prevenir la "revolución socialista" e "intervenir permanentemente en la política nacional, pero de manera claramente subordinada a la elite civil dirigente."3

Carlos Maldonado, a su vez, en su texto La Milicia Republicana: historia de un ejército civil en Chile, 1932-1936, sostiene que "la Milicia Republicana (fue) un verdadero ejército armado, de evidente connotación burguesa y conservadora y de una amplia base de masas de capas medias, (cuyo) discurso fue de restauración, de regreso a la convivencia oligárquica de antes de 1920." En esa perspectiva, -agrega Maldonado- la Milicia buscaba "el acatamiento del liderazgo civil por parte de los militares y el disciplinamiento de las masas populares. Es por ello que -añade- (sus) grandes enemigos fueron el militarismo y el comunismo." 4

De nuestra parte, abordamos el tema intentando evidenciar un aspecto que los mencionados autores no han considerado. A saber, el carácter ambivalente de la Milicia. Esto es, la pluralidad de objetivos que coexistían, o se traslapaban, en su interior, cuestión derivada de la diversidad de fuerzas e intereses que terminaron pesando en su desenvolvimiento.

En este sentido, en la Milicia Republicana, a nuestro juicio, es posible distinguir a lo menos la confluencia de tres elementos esenciales. Por un lado, figuran ciertos profesionales prósperos y de prestigio, sobre todo médicos y abogados- que fueron los principales creadores de la entidad y que ocuparon un papel importante en su dirección,

\footnotetext{
${ }^{1}$ Verónica Valdivia, Las Milicias Republicanas. Los civiles en armas, 1932-1936, DIBAM Centro de Investigaciones Barros Arana, Santiago, 1992, p.22.

${ }^{2}$ Gonzalo Vial, Historia de Chile (1891-1938) Volumen V, De la república Socialista al Frente popular (1931-1938), Editorial Zig-Zag, Santiago, 2001, p.285

${ }^{3}$ Felipe Portales, Los mitos de la democracia chilena, volumen II. Desde 1925 a 1938 . Editorial Catalonia, Santiago, 2010, p. 231.

${ }^{4}$ Carlos Maldonado, La Milicia Republicana: historia de un ejército civil en Chile, 1932-1936, Santiago, 1988
} 
caracterizándose por profesar cierto ideologismo nacionalista. Por el otro, figuran elementos empresariales y, en general, ligados a la oligarquía. A estos cabría agregar el tercer componente, compuesto por miembros del Partido Radical, el que por un tiempo fuera parte del gobierno de Alessandri.

Esta pluralidad de confluyentes, más allá de los elementos comunes que compartieran, inevitablemente tenía que dar lugar, dentro de la Milicia, a énfasis políticos e ideológicos distintos, o, como se dijo arriba, traslapados, correspondientes a diversos objetivos. Por el momento no afirmaremos que esos distintos énfasis coincidieran exactamente con los respectivos grupos que convergieran en la entidad. Sin perjuicio de ello, parece claro que a los participantes más vinculados a los partidos conservador y liberal, -que eran los partidos de la oligarquía- la Milicia les interesaba como elemento disuasivo armado en la perspectiva de descabezar el ejército poniendo así fin al peligro que representaba para ellos la mesocracia uniformada de trayectoria anti oligárquica remontable a 1924, descabezamiento que, luego de la caída de Ibáñez, los sectores oligárquicos consideraron indispensable a los propósitos de estabilizar su dominación. Esta, por cierto, debía consolidarse de manera distinta a la tradicional de corte parlamentario, lo que suponía aceptar el presidencialismo fuerte consagrado por la Constitución de 1925, todo dentro de una "racionalidad burguesa de tendencia liberal", aunque autoritaria. Desde esta óptica, la oligarquía, autodefinida como "civilista", podía reivindicar frente a los militares la idea de democracia. Por su parte, los componentes vinculados al Partido Radical, coincidían en el rol de la Milicia como factor contribuyente al sometimiento del ejército al poder civil, aunque ello en vistas de sus propios intereses corporativos y el de sus clientelas, los que no podían satisfacerse sino dentro del orden constitucional. Desde esta perspectiva, los radicales le aportarán a la Milicia, sobre todo en sus orígenes, un vínculo retórico con el orden democrático y con la reivindicación de la soberanía del pueblo, que los uniformados negarían. Por tanto, había en este particular punto cierto terreno común, dentro de la Milicia, entre los componentes oligárquicos y los del PR. En cambio, para otros partícipes de ella, -que crecientemente profesaban concepciones de corte nacionalista- la entidad, junto con servir a los efectos de poner fin al ciclo de intervencionismo militar, debía tener un propósito más refundacional y menos vinculado a la "racionalidad liberal". En tal sentido, este segmento concebía a la Milicia como una entidad contra revolucionaria permanente, cuya misión, en consecuencia, no se agotaba en la mera neutralización del ejército sino que -siguiendo el ideologismo espenglereano de Edwards- debía orientarse, en una estrategia sin tiempo, a la superación de lo que, a su juicio, sería la decadencia de la nación, ello en la perspectiva de retornar al apogeo de la misma. Esto, a su parecer, implicaba erradicar el comunismo y revitalizar la supuestamente viciada subjetividad nacional, la que (al menos en parte) se hallaría influida por aquel.

El referido carácter ambivalente que fuera propio de la Milicia Republicana explica, por otra parte, el que ella siempre mantuviera una autonomía relativa respecto del núcleo oligárquico y del gobierno de Alessandri, el que, de modo instrumental, durante un tiempo la apoyó decididamente. También explica que el desarrollo del proceso político nacional, 
con los desenlaces que fue produciendo, estimulara la eclosión de las contradicciones internas que eran inherente a la ambivalencia de la Milicia, lo que terminará por conducir a la disociación de los elementos que antes confluyeran en ella. Primero, en efecto, se retiraron los radicales y, luego que Alessandri depuró el ejército, el gobierno gradualmente le retiró su apoyo, lo que se tradujo en que en las filas de la Milicia permanecieron, aislados, principalmente sus elementos nacionalistas, los que finalmente disolvieron la entidad para generar una organización política de corte antiliberal.

En el presente artículo nos proponemos, por un lado, argumentar las referidas tesis sobre la Milicia Republicana y, por el otro, caracterizar su ideologismo más recurrente, el que a nuestro juicio era de tipo nacionalista, el que se articulaba en torno a la dialéctica de apogeo y decadencia, representando el punto de vista de su segmento más orientado a una estrategia refundacional del país.

\section{Algunos antecedentes}

Para abordar el tema se hace previamente necesario detenerse, de modo sumario, en los factores que enfrentaban a la mesocracia militar con la oligarquía.

Como se recordará, la irrupción política de la oficialidad joven de tendencia mesocrática verificada a comienzos de septiembre de 1924 (el "ruido de sables"), -que fuera seguida por la renuncia de Arturo Alessandri-, representó una etapa superior en la crisis de la dominación tradicional de la oligarquía, que por casi veinticinco años había operado mediante el sistema parlamentario. Se podría decir que esa irrupción de los uniformados, así como también el golpe del 23 de enero de 1925 que ellos dieran en contra de la Junta del general Altamirano, -quien pretendiera restaurar la cuestionada dominación oligárquicafueron, en cierto modo, consecuencia de la incapacidad que mostrara la mesocracia civil para desplazar por sí misma a la oligarquía tradicional e imponer en el país un orden más meritocrático. Ante dicha incapacidad fue la mesocracia militar la que pasó a encabezar esa lucha.

En tal marco, cuando después del referido golpe de enero de 1925 los militares acordaran llamar a Alessandri para que, a partir de marzo, terminara su periodo presidencial, lo hicieron exigiéndole el cumplimiento de dos condiciones. La primera: que no gobernara a su árbitro, sino limitándose a ejecutar el programa del reformismo militar, entonces sintetizado en el Manifiesto del 11 de septiembre, el cual, entre otras cosas, -aparte de denunciar la generalizada corrupción existente- postulaba la necesidad de instaurar un régimen de presidencialismo fuerte. La segunda condición que la juventud militar le impuso a Alessandri fue que no gobernara con los viejos prohombres de la oligarquía. Adicionalmente, -a través de una carta firmada por el ministro de Guerra, Carlos Ibáñez-, se le advirtió que debía tener mano firme con los sectores oligárquicos, por un lado, pero también con el movimiento obrero clasista, por el otro, al tiempo que se le señaló que su gobierno debía apoyarse en la clase media, con cuyos miembros debía conformar su gabinete. Ese fue el compromiso que el movimiento joven militar le impuso a Alessandri. 
Como es evidente, a través de ello debía consolidarse el desplazamiento de la oligarquía tradicional de la conducción del Estado.

Dadas esas circunstancias, entre marzo de 1925 y febrero de 1927 se desplegó una intensa lucha política entre la mesocracia militar, encabezada por el coronel Carlos Ibáñez del Campo, -detentadora del poder fáctico-, y la oligarquía, secundada por algunos sectores mesocráticos de la clase política que ocupaban asientos en el Congreso, -detentadores del poder formal- lucha que hemos descrito en otra parte. ${ }^{5}$ Esa lucha se resolvió en favor de los uniformados y de su líder, Carlos Ibáñez, el que, a comienzos de 1927, finalmente estableció su dictadura, procediendo a implantar el "termocauterio arriba y abajo". Esto es, intensas medidas represivas contra parlamentarios y líderes tanto de la oligarquía como del movimiento obrero clasista.

La dictadura de Ibáñez, apoyada por el ejército, - junto con establecer un régimen policial en el país-, reestructuró el Estado, modernizándolo. En esa línea integró a su gestión a nuevos estratos de profesionales, desplazando al personal político a través del cual gobernara la oligarquía tradicional, a la par que inició la intervención estatal en la economía. De tal modo, se consolidó una tendencia visible desde el gobierno de Alessandri, una de cuyas facetas principales fuera la inserción de las clases medias en la alta dirección del aparato estatal.

La caída de Ibáñez en julio de 1931, resultante de la crisis económica de 1929, -crisis que llevara al caudillo a perder el apoyo de las clases medias, las que se pusieron beligerantemente en su contra confluyendo con la preterida oligarquía-, dio lugar a un vacío de poder que configuró una verdadera crisis del Estado. Ello se tradujo en la imposibilidad de estabilizar el orden institucional. Indicadores de lo dicho fueron la insurrección de la marinería, de septiembre de 1931, el golpe de Marmaduke Grove, del 4 de junio de 1932 y, en parte, las fugaces dictaduras de Dávila y del general Blanche, del mismo año. A lo que, en fin, se sumaba la negativa de amplios segmentos de la mesocracia militar, todavía ibañista, a retornar a los cuarteles, cuestión expresada en sucesivas conspiraciones.

Como parte de esa crisis, pareció que el aparato militar del Estado tendía a descomponerse, al menos en alguna medida. Muchos, sobre todo entre la oligarquía y la alta mesocracia, sintieron que parte del mismo se articulaba con las clases subalternas, lo que, a su juicio, podía llevar al país a una revolución soviética. Los dos eventos que contribuyeron decisivamente a generar esa visión fueron la mencionada insurrección de la marinería, de septiembre de 1931, la que se reputó como organizada por el Partido Comunista, y la instauración de la República Socialista de Grove, quien pronto fue igualmente reputado como funcional a ese partido. Un poco antes, en diciembre de 1931 se había producido un asalto al regimiento Esmeralda de Copiapó, en el que participó un par de suboficiales del

\footnotetext{
${ }^{5}$ Véase, Luis Corvalán Marquez, Nacionalismo y autoritarismo en Chile. Los orígenes, 1903-1931, Ediciones Universidad Católica Silva Henríquez, Santiago, 2009, Quinta Parte, capítulos IV y V.
} 
ejército y miembros del PC local, lo que fue visto por las clases altas como otro indicador de la inminencia de la revolución.

Todo lo dicho, en la subjetividad de los sectores pudientes, configuraba un cuadro de extrema gravedad, cuyo significado principal estaba constituido por el sentimiento de que las FF.AA., -particularmente el ejército-, no garantizaban su predominio de clase, como es lo normal en un Estado burgués. Se temía, que ciertos sectores de los uniformados se aliaran con las clases subalternas. Aún luego de la caída de la República Socialista, -la que habría sido la expresión más palmaria de lo dicho-, ese peligro, a juicio de los sectores altos, no se hallaría del todo conjurado, y se prolongaría en las persistentes conspiraciones llevadas a cabo por parte de la mesocracia militar contraria a la oligarquía. De allí que para ésta, -que se auto presentaba como "civilista"-, fuera un objetivo de primer orden someter a dicha mesocracia uniformada.

En este marco cabe preguntarse cuanto de verdad había en los descritos temores de la oligarquía y de los sectores acomodados en general. Al respecto cabe decir que gran parte de esos temores -particularmente los referentes a la revolución soviética- no tenían base alguna. Lo que sí había era una creciente protesta popular derivada de las dramáticas condiciones de vida que afectaban a las mayorías. No obstante, los mencionados temores si tenían alguna base en lo que decía relación con la mesocracia del ejército. Dentro de esta, existía, en efecto, un considerable sentimiento anti oligárquico dispuesto a traducirse en conspiraciones golpistas.

Una muestra de la sensibilidad anti oligárquica que caracterizaba a buena parte de tal mesocracia nos la da el relato que, años después, rememorando los acontecimientos, hiciera el entonces subdirector de la Escuela de Infantería de San Bernardo, coronel ® Aurelio Concha. Este recuerda que "cuando subió al poder Juan Esteban Montero, se apreció de inmediato que (el país) retrocedería a los días anteriores al año 1924 (debido a) la influencia que (en ese gobierno) tuvieron los partidos tradicionalistas, especialmente el Conservador y el Liberal." El coronel Concha agrega que por entonces "la miseria que hundía al país necesitaba de un Mandatario que planteara realizaciones inmediatas y que sin dilación evitara la presencia de la oligarquía en el poder." ${ }^{6}$ En otra parte el coronel agrega que, a la fecha, "era impresionante la miseria humana y, cómo a todos nosotros (los militares) le llegaban diariamente las quejas y los comentarios de la situación aflictiva por la que atravesaba el país."7 Era en esas circunstancias que el descontento de la mesocracia del ejército, -que tenía ya su tradición anti oligárquica-, tendía a aflorar, normalmente a través de conspiraciones golpistas.

\footnotetext{
${ }^{6}$ Wilfredo Mayorga, Así comenzaron las conspiraciones, entrevista al coronel en retiro, Aurelio Concha,, en "Crónicas Políticas de Wilfredo Mayorga, del "Cielito lindo" a la Patria joven," Fuentes para la Historia de la República, Volumen XI, Recopilación, Rafael Sagredo, DIBAM, RIL y Centro de Investigaciones Barros Arana, Santiago, 1998, p. 417, 418.

${ }^{7}$ Wilfredo Mayorga, entrevista citada, p. 418.
} 
De este modo, durante los años siguientes a la caída de Ibáñez, el antagonismo entre la oligarquía y la mesocracia uniformada, que habían apoyado a Ibáñez, era real.

A esto se agregaba otro factor. A saber, la emergencia del descontento popular derivado de las extremas condiciones de vida que lo afectaban, agudizadas por los efectos que tuviera en Chile la crisis mundial. Ese descontento influyó en el alza de las luchas sociales y, por tanto, en la reaparición entre las clases dominantes, del fantasma de la revolución y el comunismo.

\section{Las opciones estratégicas de la oligarquía a comienzo de los años treinta}

¿Cómo reaccionó la oligarquía frente al cuadro arriba descrito? La orientación política que frente a éste ella terminó siguiendo presenta rasgos distintos si se la compara con ciertas situaciones entonces en curso en Europa. En Chile, en efecto, a diferencia del caso italiano y el alemán, la oligarquía, frente a los obstáculos que encaraba, no hizo entrar en crisis de representación a sus partidos tradicionales -el conservador y el liberal- para apoyar a los fascismos. Es decir, a los llamados "nacistas", -organizados desde junio de 1932-, o a variantes análogas representadas por otras corrientes nacionalistas y corporativistas. Lo que ciertamente no significa que no existieran sectores oligárquicos que, al menos por un tiempo, vieran con simpatía al MNS o a otras fórmulas antiliberales conservadoras. Pero, como tal, la oligarquía chilena, más allá de ciertas vacilaciones y disidencias, terminó refugiándose en el orden demo liberal, aunque en una versión autoritaria y represiva respaldada, en cuanto a esto último, en una legislación ad hoc.

En este sentido, será el liderazgo de Arturo Alessandri el que marcará el camino. El mandatario, en efecto, se orientó a consolidar la dominación oligárquica a través de la estabilización de la institucionalidad consagrada por la Constitución de 1925, lo que debía ir unido a una legislación, elaborada ad hoc, -como lo fue la Ley de Seguridad Interior del Estado- que permitiera una fuerte represión discrecional sobre las fuerzas contrarias, represión que operaría mediante Carabineros e Investigaciones. A todo ello se sumaría la inclusión del Partido Radical al gabinete, lo que suponía las correspondientes medidas de cooptación.

Fue a partir de esas premisas que Alessandri -junto a conservadores, liberales y gran parte de los radicales- decidió apoyar la conformación de una fuerza armada paralela constituida por civiles, -creada con un poco de antelación-, la que debía ayudar a neutralizar a la mesocracia militar inhibiendo cualquier intentona golpista por parte de ésta, permitiendo luego el descabezamiento del ejército, imponiéndole al mismo una doctrina de no deliberación y acatamiento al poder civil (oligárquico), confinándolo en sus cuarteles. Tal fue, en efecto, la fórmula que terminó primando al interior de la oligarquía. Demás está decir que la referida fuerza armada paralela civil fue la Milicia Republicana. 


\section{La opción de cierto estrato de profesionales de alto prestigio}

Hubo otro sector social que respondió con presteza frente a la crisis que a la caída de Ibáñez experimentara el país. Fue un segmento de la alta mesocracia, profesionales de prestigio -médicos, abogados, etc.- cuyos colegios habían apoyado la restauración civilista traducida en el gobierno de Montero. Este segmento adoptó su propia posición frente a los acontecimientos en curso.

Todo indica que ellos vivían una verdadera crisis ideológica y política. Durante los años anteriores, como parte de su oposición al núcleo oligárquico, se habían apartado del liberalismo partitocrático -al que habían asociado a intereses particulares y a la corrupcióninclinándose por la dictadura del hombre providencial, que fuera Ibáñez, del que después también se desilusionaron apoyando activamente su derrocamiento.

¿Cuáles fueron las convicciones que a la caída del caudillo esos grupos de profesionales parecieron aferrarse? Ellas parecían estar centradas en una voluntad de garantizar la continuidad institucional poniendo fin al ciclo de intervencionismo militar iniciado en 1924, al que conceptuaron como un factor de la crisis nacional y expresión de la decadencia que afectaría al país. El cierre de ese ciclo, debía, a su juicio, hacer posible la existencia de un gobierno fuerte, por sobre intereses particulares, el que debía renovar política e ideológicamente al país permitiéndole superar la decadencia a que estaría afecto, lo cual tendría como pre requisito sanear los hábitos políticos $\mathrm{y}$, en general, la cultura cívica existente (que era de corte liberal). Conseguidos estos objetivos, el país retornaría a la fase de auge o apogeo que lo habría caracterizado a mediados del siglo XIX. Como se ve, este segmento de profesionales tendía a empalmar con un discurso de claros perfiles nacionalistas y, en consecuencia, antiliberales, en lo cual es posible percibir un matiz político diferencial no menor en relación a las perspectivas del núcleo oligárquico.

A este grupo de profesionales de prestigio le corresponderá un rol fundamental en la creación de la Milicia Republicana, a la cual, por tanto, concebirán como un instrumento que no sólo debía contribuir decisivamente a poner fin al intervencionismo militar, sino también a la reversión de la decadencia nacional. Este objetivo, por cierto, tenía un alcance de largo plazo.

\section{El Partido Radical y la Milicia Republicana}

También es necesario considerar la posición que a la fecha adoptó el Partido Radical. Al respecto hay que decir que luego del derrocamiento de Esteban Montero, la actitud de esta colectividad se caracterizó por un acentuado antimilitarismo. Téngase en cuenta que Montero pertenecía a sus filas.

Se puede afirmar que la estabilidad institucional constituía el marco más adecuado para la realización de la política de este partido y para la satisfacción de los intereses corporativos que representaba, así como también el de sus clientelas. Era bajo esta lógica que el PR, - 
signado por un fuerte carácter pragmático-, siempre buscaba insertarse en los gobiernos. Las recurrentes intervenciones militares que advinieran desde 1924 en adelante, eran un obstáculo para ello. Es en tal marco que habría que visualizar el antimilitarismo que por entonces caracterizó a la colectividad. Teniéndolo en cuenta no resulta tan extraño que en la Asamblea Radical de Santiago, luego de la caída de Montero, se haya llegado incluso a discutir la propuesta de disolver el ejército, y en otra oportunidad, la necesidad de reducir sustancialmente sus recursos y efectivos, lo que incluía cerrar la Escuela Militar.

En virtud de tales antecedentes no sorprende que el grueso del PR apoyara a la Milicia Republicana. Una parte considerable de sus militantes se integrará a sus filas. Incluso más, uno de los dirigentes principales de la Milicia, el doctor Sótero del Río, pertenecía al radicalismo, mientras que otros miembros del partido pronto pasaron a ocupar puestos claves dentro de esta organización armada.

Lo dicho, ciertamente, no niega que en el PR hubiese sectores doctrinarios que no podían aceptar la existencia de un ejército de civiles. Fueron tales sectores los que, dentro del partido, siempre le negaron su apoyo a la Milicia. Pero no fue el caso de la mayoría. Para esta la Milicia Republicana no era sino un instrumento útil a los efectos de impedir que los militares quebraran el orden institucional, cuya vigencia, como dijimos, era la premisa de la política del partido y de la realización de los intereses corporativos que representaba. Por eso es que cuando la Milicia parezca ir más allá de la mera neutralización de los uniformados, el PR la abandonará, contribuyendo con ello a su decadencia y disolución.

\section{La formación de la Milicia Republicana}

La Milicia Republicana fue formalmente creada el 24 de julio de 1932. Su conformación, en todo caso, debe ser vista en el contexto de una vieja tradición existente no sólo entre los sectores oligárquicos, sino también de propietarios y estratos acomodados en general, tradición que consistía en formar Guardias Blancas armadas al margen de la Constitución y la ley toda vez que se sintieran amenazados por la protesta de las clases subalternas y cuando, a los efectos de conjurar esa amenaza, las FF.AA. fueran insuficientes, o se hallaran geográficamente lejos del escenario de conflicto.

Se podría sostener que esta práctica registra un primer antecedente en la creación, después de la guerra civil de 1830-, de las Milicias Cívicas por Diego Portales, las cuales debían servir de contrapeso al ejército, fuertemente purgado, pero todavía sospechoso de albergar en su seno a oficiales liberales.

A comienzos del siglo XX análoga modalidad, bajo formas distintas, fue reasumida por sectores oligárquicos y patronales en general, aunque con otros propósitos. Estos consistían en enfrentar y reprimir, sin amarras legales, la emergencia de las luchas obreras.

Una variante que entonces adoptaron las Guardias Cívicas fueron las Ligas Patrióticas, las que a partir de 1911 se formaron en distintas partes del país, sobre todo en el norte. Las 
Ligas, junto con usar la violencia en contra de la población peruana residente en Tarapacá, pronto empezaron a hacer lo propio en contra de las organizaciones obreras anticapitalistas, a las cuales acusaban de estar financiadas por el "oro peruano". El quehacer de las Ligas, de manera intermitente, se extendió entre 1911 y 1920. Después de esta fecha empezaron a decaer hasta desaparecer.

Aparte de las Ligas, en ocasiones, cuando no contaban con suficiente respaldo del Ejército o de la policía, los dueños o administradores de oficinas salitreras acostumbraban crear diversas Guardias Blancas a los fines de enfrentar huelgas obreras.

Luego de las intervenciones militares de septiembre de 1924 y enero de 1925 la oligarquía creó Guardias Blancas para oponerse a los uniformados, las que, "con armas y municiones compradas en Argentina", ${ }^{8}$ solían ser entrenadas en fundos de los alrededores de Santiago. No es menos cierto que, a la misma fecha, la Alianza Liberal procedió a organizar una fugaz Guardia Cívica cuyo propósito era apoyar al movimiento militar. A la caída de Ibáñez fueron organizadas otras Guardias, las que debían garantizar el orden y la propiedad privada cuando los militares y carabineros, ante el estallido de masas, se refugiaran en sus cuarteles.

La insurrección de la marinería dio lugar a la creación de nuevos grupos armados civiles entre los sectores conservadores, los que se formaron en diversos puntos del país, organizados por distintos sectores patronales, no sólo oligárquicos. A modo de ejemplo, entre otros- por entonces, "en la provincia de Aconcagua, los comerciantes organizaron guardias cívicas para la |defensa de sus negocios y propiedades." ${ }^{9}$ Las Guardias Blancas también se expandieron por Copiapó y Vallenar. Ello en respuesta a la eclosión de la protesta popular que se verificara en la zona derivada de la situación generalizada de desempleo y hambre que afectaba a los sectores populares. Carlos Maldonado en el apéndice de su investigación sobre la Milicia Republicana, contabiliza en cuarenta y tres las Guardias Cívicas que se formaron en el país sólo entre 1931 y 1937.

Las Guardias Blancas, o Guardias Cívicas, normalmente se constituían como fuerzas que debían actuar como reservas de las instituciones del Estado y, por tanto, de la autoridad civil. Apuntaban en contra la protesta popular y, más tarde, durante los años treinta, en contra de lo que algunos consideraron como conatos de rebelión militar vinculados al pueblo, como habría sido el caso de la rebelión de la marinería. Tales Guardias, por tanto, representaban fuerzas de reserva de la dominación. Ideológicamente tendían a tener una definición nacionalista y anticomunista articulada en torno a las ideas de orden y autoridad.

La instauración de la República Socialista de Grove estimuló la consabida tendencia a constituir Guardias Cívicas. Entre ellas la más importante fue la Milicia Republicana, la

\footnotetext{
${ }^{8}$ Verónica Valdivia, Las Milicias Republicanas. Los civiles en armas, 1932-1936, DIBAM Centro de Investigaciones Barros Arana, Santiago, 1992, p. 15.

${ }^{9}$ Verónica Valdivia, op. cit., p.18.
} 
que, de este modo, por tanto, no hizo sino continuar con una vieja tradición existente entre los sectores conservadores. Pero con una salvedad. A saber, que se constituyó, en lo inmediato, no sólo para enfrentar el peligro de un levantamiento popular, sino también a la mesocracia ibañista del ejército y su tendencia a intervenir en política sin actuar bajo el control oligárquico, como había ocurrido desde septiembre de 1924 en adelante, tendencia que parecía no poder detenerse.

\subsection{Los comienzos de la Milicia Republicana}

Como se dijo arriba, la Milicia Republicana fue fundada, bajo la dictadura de Dávila, el 24 de julio de 1932.Sus creadores fueron personeros provenientes principalmente de los sectores de la alta mesocracia, particularmente profesionales de prestigio, médicos, abogados e ingenieros, cuyos colegios habían apoyado la restauración civilista traducida en el gobierno de Montero, a los que se agregaban individuos procedentes de las clases más elevadas, empresarios y latifundistas.

Quienes dieron vida a la Milicia lo hicieron ciñéndose a pautas altamente conspirativas. En efecto, conformaron grupos secretos que se movían en la clandestinidad y que decían tener la pretensión de constituir una fuerza armada que oponer al recurrente golpismo militar, al que, a su vez, concebían como la expresión de algo más profundo. A saber, una pronunciada decadencia nacional que debía ser revertida, incluso con las armas.

Hubo un grupo que en este quehacer precedió a la Milicia, y que después se uniría a ella. Fue la UNA, sobre la cual debemos hacer algunas referencias. Sus líderes principales fueron los doctores Sótero del Río y Julio Schwarzenberg. Al parecer, desde mediados de 1932, la entidad desarrolló una intensa actividad dirigida a captar miembros, siempre de modo clandestino. Fernando Altamirano, partícipe de los hechos, rememora dicha actividad y hace referencias al nombre con el que la organización fuera inadvertidamente identificada. Al respecto sostiene que muchos de los que recibían la proposición de integrarse a ella "daban la misma respuesta:"yo ya pertenezco a una, y no sabían que era la misma", relata Altamirano. No lo sabían, -agrega- ni el reclutador ni el candidato ya reclutado por otro. Así la frase: "yo ya pertenezco a una" -añade- se fue haciendo conocida, y sin quererlo ni desearlo a fuerza de oír que ya se estaba en "una" o se pertenecía a "una", la organización innominada pasó a llamarse simplemente "La una"....Corrían los días del gobierno de Dávila." ${ }^{10}$

-Más tarde, "La Una" pasó a llamarse "Una Tricolor". En razón del carácter clandestino de sus actividades, -sostiene Altamirano- sus promotores "cambiaban diariamente los sitios de sus reuniones y los lugares donde se guardaban los tarjetones (que contenían la lista) de sus adeptos." Asistían a las reuniones de la entidad, -aparte de los doctores Sótero del Río y

\footnotetext{
${ }^{10}$ Wilfredo Mayorga, Crónicas de Wilfredo Mayorga, del "Cielito Lindo" a la "Patria Joven", Recopilación, Rafael Sagredo, Fuentes para el estudio de la República, V.XI, DIBAM, RIL y Centro de Investigaciones Barros Arana, Santiago, 1998, p.500.
} 
Julio Schwarzenberg-, Leonardo Guzmán; Eugenio Díaz Lira, Jorge de la Cuadra, Litré Quiroga y también el general de aviación (R) Ramón Vergara Montero. De esas reuniones relata Fernando Altamirano- salió un comando general que presidió el doctor Waldemar Coutts y de cuya existencia nadie, sino los iniciados, tenía conocimiento." ${ }^{11}$

"La UNA, que se extendió entre Santiago y Valdivia, sin embargo, careció de preparación militar y de implementos de combate funcionales a una organización de resistencia tal como fue pensada por sus fundadores." ${ }^{12}$ En subsidio, llevó a cabo un fuerte proselitismo anti socialista y en favor del orden institucional.

A la fecha, paralelamente a la UNA, se formó otro grupo de análogo carácter, pero con una mayor decisión de transformarse en una institución propiamente armada. Fue la Legión de los camisas azules, cuyos miembros fueron reclutados por el ingeniero de la Universidad Católica, Eulogio Sánchez Errázuriz. El 24 de julio de 1932, en plena dictadura de Dávila, Sánchez convocó a sus seguidores, los que, en un número de 54, se reunieron en la terraza de la Escuela de Ingeniería de la Universidad de Chile. Allí, después de una alocución patriótica que corrió por cuenta del mismo Sánchez, el grupo se constituyó en Milicia Republicana, no sin que sus miembros hicieran un juramento de lealtad a la organización. El juramento decía lo siguiente:

Juro por mi honor dar hasta la vida si fuere necesario, por imponer en Chile el sistema de Gobierno Republicano Democrático. Luchar sin temor y con las armas en la mano, si así se me exigiera, para que imperen en mi Patria el respeto a la Constitución y las Leyes. Juro asimismo, combatir por cualquier medio toda tiranía, ya sea comunista, civil o militar. Con tal fin ingreso desde este momento a la organización denominada "Milicia Republicana" y me someto_sin vacilaciones a las órdenes que reciba, las que acataré sin discutir,_guardando el más absoluto secreto. Contra todas las tiranías, por el Gobierno del Pueblo y para el Pueblo y por la libertad dentro de la Constitución."

Sin duda, el elemento más notorio de este juramento es el compromiso de los miembros de la Milicia en orden a "combatir con las armas en la mano" a los enemigos que define, los que, como se ve, eran aquellas fuerzas que se orientarían a romper el orden constitucional, -las que, como sabemos, eran ciertos sectores del ejército- a las que se agregaba el "comunismo". Igualmente es importante en el juramento, la adhesión que éste hiciera al régimen republicano democrático y al principio de soberanía popular. Estas formulaciones se entienden mejor si se tiene en cuenta que el juramento fue redactado por Justiniano Sotomayor, militante del Partido Radical.

En las semanas siguientes, el 13 de agosto, se produjo otro acontecimiento relevante. A saber, la Milicia Republicana absorbió a la UNA. El hecho, según el relato de Fernando Altamirano, se verificó cuando "Eulogio Sánchez organizó una concentración con los primeros cien milicianos en un claro del fundo Macul, de los Cousiño," lugar significativo -

\footnotetext{
${ }^{11}$ Wilfredo Mayorga, op. cit., p.500.

${ }^{12}$ Verónica Valdivia, op. cit., p. 25.
} 
agreguemos- en la medida en que muestra una conexión de la Milicia con la oligarquía. Fernando Altamirano relata el evento en los siguientes términos: "no faltaron en este acto las arengas patrióticas a cargo del propio Eulogio Sánchez y del doctor Andrés Prado Reyes, ni las evoluciones y movimientos militares al mando de Ramón Vergara Montero, y en medio de todo se realizó la ceremonia del "paseo de la bandera", actuando como abanderado el doctor Eugenio Díaz Lira. Los jefes de la "La Una", -continúa el relato de Altamirano- que habían sido invitados, vieron con entusiasmo cómo actuaban los hombres de las Milicias Republicanas y acordaron allí mismo la unión de las dos entidades vaciando todos los efectivos de "La Una" en la Milicia Republicana, constituyéndose de inmediato un Estado Mayor, cuyo comandante fue Eulogio Sánchez, integrado por el doctor Julio Schwazenberg como presidente, y Sótero del Río, Ricardo Kushel, Ítalo Alessandrino, José Andrés Prado Tagle, Diego Sutil Prieto, Jorge de la Cuadra y Julio Bustamante como vocales." ${ }^{13}$ La Milicia allí mismo adoptó como uniforme un overol azul oscuro, un gorro del mismo color y un cinturón de cuero.

Después del mencionado evento, la Milicia Republicana se fue extendiendo a lo largo del país, -entre Tarapacá y Magallanes- en un comienzo de modo clandestino, organizándose en regimientos, cuya base estaba formada por gente de distintos estratos de las clases medias, y uno que otro joven de clase alta. Tales regimientos -que estaban bajo un mando nacional centralizado constituido por un Estado Mayor- distaban mucho de ser simbólicos. Por el contrario, de inmediato se dieron a la tarea de recibir la instrucción militar que los habilitara para hacer uso efectivo de las armas, contando para estos efectos con la asesoría de militares en retiro.

Fernando Altamirano, quien asumiera el cargo de general comandante provincial de Santiago, relata que desde entonces, "uno de los centros de instrucción que estaba siempre abierto a todos los milicianos, aunque no fuesen de la unidad correspondiente, fue la mansión de Miguel Luis Amunátegui, en Alameda con Amunátegui, la conocida "casa colorada" de la tradicional familia. El miliciano Miguel Luis Amunátegui Johnson, hijo de don Miguel Luis, -agrega Altamirano- obtuvo de su padre autorización para desmantelar sus salones con el objeto de convertirlos en campos de instrucción." ${ }^{14}$ Esta se realizaba durante la noche hasta altas horas de la madrugada. Otros lugares donde se llevaba a cabo análoga actividad, tanto en Santiago como en provincia, fueron los fundos de terratenientes afectos.

Para los fines de la mencionada instrucción, Eulogio Sánchez resolvió se fabricaran fusiles de madera, de peso y tamaño similar a los mauser. Luego, viendo que ello era insuficiente para una adecuada preparación, se optó por copar los clubes de tiro, de los cuales los milicianos debían hacerse socios. Al respecto, relata Fernando Altamirano, "en pocas semanas, la cantidad de nuevos adeptos a los polígonos fue tan grande, que pudieron cambiar las directivas, y ante el mayor interés de los ciudadanos por instruirse en el manejo

\footnotetext{
${ }^{13}$ Wilfredo Mayorga, op. cit., p.502.

${ }^{14}$ Wilfredo Mayorga, op. cit., p.502.
} 
de las armas, fue fácil iniciar una serie de nuevos pedidos de armas, variar las horas de funcionamiento del club, y realizar instrucciones muy de mañana (entre 6 y 8) para que los milicianos pudieran llegar a sus sitios de trabajo en las horas correspondientes." En otros casos se instauró la práctica de retirar el armamento de los clubes en la noche para llevarlo a los lugares de instrucción -fundos de los alrededores- y, luego de cumplida ésta actividad, devolverlos a sus lugares de origen en la mañana a primera hora. Así por varios meses. Altamirano relata que pronto las Milicias pudieron importar " un número discreto de armas nuevas." 15

Demás está decir que el uso de la mansión Amunátegui para los efectos de instrucción militar, y de fundos de los alrededores, tanto como el financiamiento de los uniformes y la compra de "armas nuevas", evidencian desde ya la temprana conexión que tuvo la Milicia Republicana con la oligarquía, propietaria de los mencionados fundos y que era la única que tenía los recursos económicos para hacer los desembolsos requeridos por la adquisición de los implementos de todo tipo que la entidad demandaba. Sobre este tema volveremos más adelante.

\subsection{La composición social de la Milicia Republicana}

La composición social de la Milicia Republicana era diversa. Según Carlos Maldonado, los que la dirigían "poseían orígenes evidentemente oligarcas y burgueses, reflejados en sus estrechos vínculos con la Sociedad Nacional de Agricultura, la sociedad de Fomento Febril, el Club Hípico y ...el Club de la Unión, además de (su vinculación con)los partidos políticos llamados "históricos", liberal y conservador, y el sector más derechista del Partido Radical." 16 Se trataba de hombres de fortuna. Junto a ellos, por otra parte, hay que agregar a cierta capa de profesionales de las carreras más prestigiosas, médicos, abogados. A estos grupos de profesionales, como hemos visto, les correspondió un rol importante en le creación de la entidad. A ellos hay que agregar altos oficiales en retiro de las Fuerzas Armadas, generales, almirantes, etc.

Un tercer segmento de la Milicia, muy mayoritario, pertenecía a las clases subalternas, empleados, pequeños empresarios y comerciantes, trabajadores por cuenta propia y algunos obreros, todos los cuales se desempeñaban como parte de la tropa y de la baja oficialidad del organismo. Según Maldonado, la militancia de estos sectores en la Milicia les daba la posibilidad de relacionarse y escalar socialmente, que era lo que muchos buscaban.

\section{Los cambios políticos de fines de 1932 y la Milicia Republicana}

Durante los últimos meses de 1932 se verificaron en el país importantes cambios políticos. Estos influyeron decisivamente en el quehacer de la Milicia Republicana. Entre tales cambios cabe mencionar la caída del gobierno de Dávila, el 13 de septiembre, el que

\footnotetext{
${ }^{15}$ Wilfredo Mayorga, op. cit., p. 504.

${ }^{16}$ Carlos Maldonado, op. Cit.
} 
fuera reemplazado por el del General Blanche, quien nombró un ministerio de claras tendencias ibañistas. Entonces no faltaron quienes vieron en este gobierno un mero prolegómeno del retorno de Ibáñez al poder. En tales circunstancias, la Milicia Republicana se acuarteló y realizó labores de vigilancia sobre los militares. Blanche, por su parte, renunció pronto. Lo hizo el primero de octubre, presionado por los movimientos cívicos que influyeron profundamente entre los uniformados, -sobre todo en las guarniciones de Antofagasta y Concepción-, quienes se hallaban cansados de la politización militar y de las divisiones internas que ésta había generado entre las instituciones de la defensa. Renunciado Blanche, el gobierno recayó en el presidente de la Corte Suprema, Abraham Oyanedel, quien procedió a convocar a elecciones presidenciales, las que celebradas el 30 de ese mes, dieron como ganador a Arturo Alessandri. Este asumió el mando a fines de diciembre $\mathrm{y}$, a diferencia de su primera administración, pasó a gobernar con el núcleo oligárquico y sus partidos, -el conservador y el liberal-, a los que sumaron los radicales, convenientemente cooptados.

Otro hecho relevante que se verificó entonces fue la renovación del Congreso, mediante comicios celebrados simultáneamente con los presidenciales. Un elemento adicional que hay que tener en cuenta se situó en el plano social. Estuvo constituido por la permanencia de la agitación de los sectores populares, cuestión muy vinculada a la generalizada miseria en que éstos vivían, agravada por la profunda crisis económica por la que atravesaba el país. Un poco antes, a mediados de 1932, había aparecido el Movimiento Nacional Socialista y, a mediados del año siguiente se formará el Partido Socialista, cuyo rápido crecimiento entre sectores populares se viera estimulado por la política estrechamente proletaria que por entonces seguía el Partido Comunista.

\section{Los objetivos del gobierno de Alessandri y la Milicia Republicana}

Alessandri asumió su segundo gobierno en diciembre de 1932. El objetivo principal que entonces se propuso, -que, a la vez, era del de los círculos oligárquicos- fue cerrar el ciclo político abierto en septiembre de 1924, lo que pasaba por depurar y controlar al ejército y, a la par, reprimir los brotes de protesta popular en curso derivados de la mencionada crisis económica que afectaba al país. Conseguidos tales objetivos, debía verificarse cierta restauración oligárquica, -aunque sin retornar a la vieja forma parlamentaria-, en el marco de un régimen fuerte, formalmente constitucional, que era el consagrado por la Constitución de 1925. A tales efectos Alessandri le asignará un rol relevante a la Milicia Republicana, la que, como dijéramos arriba, debía constituirse en un contrapeso armado capaz de disuadir, y enfrentar, a cualquier levantamiento militar, lo que luego debía permitir depurar al ejército y someterlo al Estado oligárquico en restauración.

Paralelamente, apoyado en una legislación ad hoc -que fue la Ley de Seguridad Interior del Estado- y sucesivas declaraciones de estados de excepción, el gobierno reprimiría a las movilizaciones populares y, en general, a los partidos opositores. 


\section{La concepción nacionalista de la Milicia Republicana}

En todo caso, al interior de la Milicia Republicana era muy fuerte una particular manera de concebir a la entidad, la que se distinguía de la que era propia del núcleo oligárquico, de Alessandri, y del Partido Radical. Esa concepción se estructuraba en torno a un ideologismo nacionalista y refundacional, basado en la dialéctica de apogeo y decadencia, que se traducía en una orientación no sólo en contra del intervencionismo militar, sino también en contra del alza de las luchas populares, a las que concebía como un factor de disolución nacional. A este respecto Carlos Maldonado señala que "la gran mayoría de los milicianos veía en esta organización principalmente un grupo de combate contra el comunismo y una reedición de las guardias cívicas de 1931, a semejanza de los Freikorps alemanes, o sea, una alianza cívico-militar contra revolucionaria." 17

Esta auto percepción de la Milicia, que se insertara dentro de una lógica nacionalista, llegó incluso a hacer que la entidad resultara atractiva para el Movimiento Nacional Socialista, muchos de cuyos miembros, en una suerte de infiltración, se incorporaron a ella sin dejar de pertenecer al MNS. Sobre el punto, un dirigente de los "nacistas", quizás exagerando los tonos, relató: "teníamos completamente penetrada la Milicia Republicana. Había regimientos enteros donde aparte de una o dos cabezas todo el resto pertenecía en silencio al MNS. Nos íbamos tomando la Milicia, pues en muchos ("nacistas") había el espíritu de darle una fuerza mayor que la política al Movimiento; y estar (con esas miras) con posibilidades de dominio en la Milicia Republicana, que tenía armas, era de la mayor importancia. Yo mismo - continúa el relato- tuve en mi casa parte de un arsenal de la Milicia y nadie sabía aún que era del MNS."18 Por su parte, el ex presidente del Partido Nacional, Victor García Garcena, quien en su juventud perteneciera a la Milicia, rememora que en el regimiento de Viña del Mar, al cual él pertenecía, "un tercio del contingente era de filiación nazi”. ${ }^{19}$

Quizás fuera ese grado de infiltración el que en septiembre de 1933, llevara al Estado Mayor de la Milicia, temeroso a perder el control de la entidad, a declarar la incompatibilidad entre la condición de miliciano y la de "nacista". Los argumentos que fundaron la medida, claro está, fueron formalmente otros. Ellos hacían mención a la incompatibilidad que existía en la adhesión a dos jefaturas "igualmente estrictas", -la del MNS y la de la Milicia- a lo que se agregaban consideraciones relativas al carácter dictatorial que tenía el proyecto del MNS, lo que no calzaría con los fines de la Milicia.

Los mencionados deslindes, en todo caso, no atentaron en contra del radicalismo nacionalista de corte espenglereano, que caracterizó a gran parte de la cúpula y de los militantes de la Milicia, quienes identificaban al comunismo como el enemigo principal,

\footnotetext{
${ }^{17}$ Carlos Maldonado, op. cit.

${ }^{18}$ Entrevista de Wilfredo Mayorga, op. cit., p.520.

${ }^{19}$ Citado por Carlos Maldonado, op. cit., p.41.
} 
culpable de la decadencia y disolución nacional. Los planteamientos que sobre el punto se hicieran a través de las publicaciones de la organización fueron recurrentes. Así, en un artículo del Boletín Informativo de la Milicia Republicana (BIMR) del 15 de agosto de 1933, se decía: "lucharemos con denuedo y perseverancia por la mantención del orden y en consecuencia por la extirpación definitiva del comunismo revolucionario". 20 Lo más notable de todo residía en que este planteamiento se hacía en circunstancias que el PC era un partido legal.

En la misma línea, José Miguel Echeñique, dirigente de la Milicia, a comienzos de 1934, en un acto de la entidad celebrado en Peñaflor, en relación al partido Comunista, sostuvo: "Esos elementos traidores, todavía pretenden destrozar aún más a este país, esos delincuentes profesionales que tan gravemente atentaron contra los fundamentales y sagrados derechos de la Nación, contra sus más vitales intereses, esos eternos demoledores están nuevamente unidos para proseguir su obra nefasta, su obra exterminadora, esa infame traición a la republica; para continuar esos atentados criminales y delictuosos contra la patria, incitando, a la lucha social, con sus programas huecos, que entrañan sólo principios de negación y exterminio."21

En el discurso nacionalista de la Milicia Republicana, "el caos y el desorden” que según su diagnóstico existiría en el país, en gran medida provendrían de "el comunismo"-, al que, por otra parte, se lo vinculaba a un centro extranjero. En el mismo artículo del BIMR citado arriba, se decía al respecto: "nuestro pueblo necesita orden y disciplina...Estamos cansados de ver tanta indisciplina y desorden, tanto desquiciamiento moral fomentado por las doctrinas nefastas emanadas de Moscú."22

Para esta vertiente nacionalista de la Milicia Republicana, la finalidad última de la organización era la re estructuración del país por la vía de transformar su conciencia, lo que suponía erradicar a los elementos que la habrían pervertido. En esa perspectiva, el control de la mesocracia militar era tan sólo un fin intermedio.

Era precisamente esto lo que subrayaba un artículo del BIMR, fechado el 18 de junio de 1935. "Recordemos previamente -se decía en él- que nuestra Institución persigue una doble finalidad: una de carácter transitorio (evitar el golpismo) que nos exige estar siempre listos para defender con las armas en la mano la paz interna de la república, y otra, de carácter permanente y que tal vez es nuestra misión fundamental, de agrupar alrededor del ideal miliciano a todos los hombres que comprendan la necesidad, imperiosa y hoy persistente tal vez durante muchos años, de formar una nueva conciencia ciudadana, que sólo mire el bien colectivo."23

\footnotetext{
${ }^{20}$ Citado por Carlos Maldonado, op. cit., p. 42.

${ }^{21}$ Citado por Carlos Maldonado, op. cit., p. 42.

${ }^{22}$ Citado por Carlos Maldonado, op. cit., p.47.

${ }^{23}$ Citado por Carlos Maldonado, op. cit., p.47, 48.
} 
Dicho con otras palabras, el objetivo final de la milicia Republicana consistiría en lograr la reconfiguración de la conciencia nacional, lo cual, entre otras cosas, -junto con eliminar el caudillismo militar- suponía la erradicación de las concepciones "emanadas de Moscú", que eran las que fomentarían el desorden y la indisciplina, expresiones de la decadencia nacional.

Como se ve, estos énfasis se distinguen claramente de los de la oligarquía, la que esencialmente viera en la Milicia sólo un instrumente para purgar el ejército y estabilizar, en la condiciones de la época, su dominación. Ni siquiera el tema del comunismo lo veía la oligarquía como abordable mediante la Milicia. Para tales fines más bien pensaba utilizar a Carabineros e Investigaciones, valiéndose adicionalmente de ciertos recursos legales creados ad hoc, como terminará siendo la Ley de Seguridad Interior del Estado, que en los hechos permitirá una represión discrecional.

\section{El traspaso de armas a la milicia republicana}

El respaldo que del gobierno de Alessandri recibiera la Milicia Republicana le dio a esta un gran impulso. La entidad, en todo caso, ya venía en alza. En efecto, en octubre de 1932, luego de la renuncia del general Blanche, había comenzado a salir a la luz pública. Incluso empezó a emitir declaraciones. En noviembre, un discurso de uno de sus líderes perfiló su ideologismo, al tiempo que la instrucción militar de sus miembros se ampliaba, junto con el proveimiento de armas, respecto de lo cual el gobierno transicional de Oyanedel, -a decir de los propios milicianos-, hacía vista gorda. A este respecto, a partir de octubre de 1932 empezó a verificarse un traspaso de armas desde Carabineros a la Milicia, cuestión que, ya bajo el gobierno de Alessandri, se prolongó al menos hasta fines de 1933.

Apenas asumió la primera magistratura, Alessandri procedió a darle un explícito apoyo político a la Milicia. En sus Recuerdos de gobierno el mandatario al respecto escribió: "comprendí la trascendental importancia de aquél organismo -la Milicia Republicana- al calor de una verdadera necesidad nacional y de un abnegado patriotismo. Le di, como era natural, mi más amplio y decidido apoyo, para que se formara y creciera." 24

Una de las principales facetas del respaldo que las Milicias recibieron del gobierno de Alessandri, fue el masivo traspaso de armas que entonces empezó a producirse en su beneficio, armas que provenían de los arsenales del ejército. Ese traspaso -como se dijohabía subrepticiamente comenzado bajo el gobierno de Oyanedel, pero se vio sustancialmente incrementado cuando Alessandri asumiera la primera magistratura. Gonzalo Vial sostiene que en total, se entregaron a la Milicia 10 ametralladoras Maxim, 24 fusiles-ametralladoras Broowning-Colt, 819 carabinas, 11.999 fusiles, y 9.000 yataganes, amén de accesorios......y un millón de cartuchos. Estos, como los fusiles, yataganes y carabinas, eran marca Mauser." Vial agrega que "soslayando obstáculos legales, la entrega

${ }^{24}$ Citado por Felipe Portales, Los mitos de la democracia chilena, V.II, Ed. Catalonia, Santiago, 2010, p.229. 
siguió una ruta desviada: Arsenales de Guerra del ejército, a Carabineros; este cuerpo, a la Intendencia, y la intendencia a la Milicia."25

Fernando Altamirano, por su parte, sostiene que, aparte de lo anterior, el gobierno de Alessandri le permitió a la Milicia "la importación de armas nuevas y algunas automáticas que sirvieron para darnos seguridad y sobre todo para que se supiera definitivamente que la Milicia Republicana se encontraba decidida a evitar nuevos asaltos al poder." ${ }^{26}$

Hasta antes que asumiera Alessandri, el peso de la Milicia Republicana como fuerza armada era menor. Las cosas cambiaron sólo mediante el decidido apoyo que el mandatario les brindó. La entidad llegaría a tener alrededor de 50.000 hombres en todo el territorio, armados y disciplinados, contando incluso con una pequeña flota de aviones.

\section{El financiamiento de la Milicia}

La mantención y crecimiento de la Milicia Republicana requería de ingentes recursos financieros. La sola compra de armas "nuevas" en el extranjero, -que complementaban a las que el gobierno le traspasara desde los arsenales del ejército-, da una idea sobre la magnitud que debieron alcanzar esos recursos. ¿De dónde procedían? No, obviamente, de las arcas fiscales, cosa que hubiera sido imposible. Venían del alto empresariado. Es decir, de los grupos oligárquicos.

Fernando Altamirano, jefe de uno de los primeros regimientos de la Milicia, sostiene que para reunir esos recursos la entidad constituyó un Comité de Finanzas, que dependía de su Estado Mayor General. Ese comité fue encabezado por Pedro Blanquier, personero ligado a la oligarquía al que Ibáñez antes de caer, nombrara como su ministro de Hacienda, pensando, vanamente, que así daría confianza a los círculos oligárquicos. Aparte de Blanquier, el comité estaba integrado por tres personeros de los grandes negocios: Víctor Eyzaguirre Hertzl, Ignacio Valdivieso Solar y Francisco Echeñique Gandarillas. ${ }^{27}$

Parte importante de los recursos financieros que recibía la Milicia -no sabemos si gestionados por el mencionado comité- provenían de los Bancos y grandes empresas, que los traspasaban bajo la forma de auspicios al Boletín Informativo de la Milicia Republicana. Verónica Valdivia sostiene que entre los más "asiduos auspiciadores" de dicho Boletín figuraban "el Banco de Chile, (el) Banco Edwards, (el) Banco Osorno y la Unión, (la) Compañía Sudamericana de Vapores, (la) Compañía de Seguros La Cordillera, (la) Pacific Steam Navegation Company, (la) Empresa de Ferrocarriles del Estado, (y) El diario Ilustrado, entre otros." 28

\footnotetext{
${ }^{25}$ Gonzalo Vial, op. cit., p.288.

${ }^{26}$ Wilfredo Mayorga, op. cit., p. 504.

${ }^{27}$ Wilfredo Mayorga, op. cit., p.510, 511.

${ }^{28}$ Verónica Valdivia, op. cit., p. 56.
} 
Las vinculaciones personales de la cúpula de la Milicia debían, por otra parte, influir en la captación de recursos desde los sectores altos de la sociedad. Téngase en cuenta que numerosos miembros de esa cúpula pertenecían al Club de la Unión. En efecto, un $50 \%$ de su Estado Mayor General era socio del mismo, entre ellos los organizadores de la UNA, Ítalo Alessandrini, Jorge de la Cuadra, Sótero del Río, Julio Schwazenberg, Diego Sutil y el fundador de la Milicia, Eulogio Sánchez. Igualmente lo era un $38.4 \%$ de su comité consultivo. $^{29}$ De este modo, en fin, las vinculaciones de clase de la Milicia se hacen patentes.

\section{El desfile del 7 de mayo de 1933 frente a La Moneda}

Constituida ya la Milicia Republicana en una fuerza armada considerable, y bien financiada, Alessandri las autorizó para que mostraran públicamente su poderío y organización, lo cual debía llevarse a cabo a través de un desfile de sus fuerzas frente a La Moneda, desde cuyos balcones el mandatario observaría el paso de sus tropas.

El desfile se verificó el 7 de mayo de 1933. Ese día pasaron frente a Alessandri, -durante una hora y cincuenta minutos, y ante un público que abarrotaba las veredas circundantes-, 14.000 hombres, perfectamente uniformados y disciplinados. Al tiempo que esto ocurría, aviones de la Milicia dejaban caer sobre Santiago una nube de panfletos, que describían los fines que ella decía perseguir. Su texto señalaba lo siguiente:

Ciudadanos: La Milicia Republicana que en estos momentos desfila por las calles de Santiago, cree representar un sentimiento vivo del alma nacional, un anhelo largamente acariciado por todos los buenos chilenos: el afianzar aquí en forma definitiva y establecer la existencia normal de los países civilizados. La Milicia es desinterés, orden, legalidad e ideal. No va contra ti, pacífico ciudadano que labras tu porvenir en silencio. Tampoco va contra ti soldado o guardián del orden que cumples con tu deber, respetando el juramento disciplinario que prestaste. Va contra el caudillo sin escrúpulo y contra el comunista sin patria. La milicia es una institución de honor...

Terminado el desfile, Alessandri, desde los balcones de La Moneda, hizo un discurso donde señaló: "el gobierno no ve en la Milicia Republicana ningún peligro y, por el contrario, ve en ella una base de seguridad institucional; autoriza su existencia y le presta amparo." ${ }^{30}$

\section{El respaldo de los poderes del Estado a la Milicia}

La presentación pública que el 7 de mayo la Milicia Republicana hiciera frente a La Moneda, suscitó de inmediato reacciones adversas entre la oposición al gobierno. El día 12, en la Cámara de diputados, Carlos Vicuña presentó una moción que establecía lo siguiente:

\footnotetext{
${ }^{29}$ Verónica Valdivia, op. cit., p. 56.

${ }^{30}$ Citado por Gonzalo Vial, Historia de Chile (1891-1973), vol. V, Ed. Zig-Zag, 2001, p. 289.
} 
"La Cámara declara que las Milicias Republicanas deben ser disueltas y sus jefes procesados por sediciosos." La moción fue rechazada. En contra votaron todos los conservadores, liberales y Agrarios presentes; y todos los radicales, con la excepción de Enrique Aguirre, quien se abstuvo. A favor votaron los socialistas, comunistas, radical socialistas, varios demócratas, Vicuña y Juan Antonio Ríos." ${ }^{31}$ En el Senado se verificó análoga situación cuando Eugenio Matte presentó un proyecto de acuerdo que propugnaba la disolución de la Milicia. Aquí, nuevamente, los partidos de la oligarquía se opusieron al proyecto y apoyaron a la entidad.

El Poder Judicial, por su parte, adoptó análoga posición. En efecto, ante una denuncia presentada ante la Corte de Apelaciones de Santiago que acusaba a la Milicia de ser contraria, con su sola existencia, al orden constitucional, el tribunal denegó la acusación. De este modo, le otorgó a la Milicia, un respaldo tácito. Así, pues, la Milicia republicana resultó recibiendo el respaldo de los tres poderes del Estado: del gobierno, de las dos cámaras del Congreso y del Poder Judicial.

Pero no sólo eso. Los apoyos vinieron también de la Armada, la que, como lo hemos demostrado en otros textos, siempre se había alineado con la oligarquía. No fue extraño, entonces, que el Director General de la institución, contralmirante Olegario Reyes del Río, -quien a decir de Gonzalo Vial, tenía dos hijos en la Milicia- a fines de mayo emitiera una declaración en la que decía, "la Armada considera conveniente a la salud de la República la existencia de las Milicias Republicanas, estimándolas como un cuerpo cooperador de sus funciones en orden a mantener la paz social y la tranquilidad interna, para que S.E. el presidente de la República pueda desarrollar su trabajo de reconstrucción nacional." ${ }^{32}$

A su vez, las relaciones entre la Milicia y Carabineros fueron estrechas y de mutua colaboración. Mientras que en el ejército, por razones obvias, aquella suscitaba un fuerte rechazo. A decir de Felipe Portales, la masacre de Lonquimay, -que dejara cientos de campesinos muertos en el alto Bío Bío- perpetrada por Carabineros, no hubiera sido posible al margen de la señalada cooperación.

\section{La depuración del ejército y su sometimiento a la civilidad oligárquica}

Los hechos descritos fueron configurando una correlación de fuerzas que permitía al gobierno oligárquico de Alessandri, emprender acciones orientadas a poner fin a la amenaza de la mesocracia militar. Ello debía operar sobre todo mediante el descabezamiento del ejército. Esto empezó a llevarse a cabo el mismo año de 1933.

Por entonces, -apoyándose en el general Novoa, que por su apoliticismo era de su total confianza- Alessandri llamó a retiro a cinco generales, quedando en la institución sólo uno de División- y tres de brigada. ${ }^{33}$ Ese año, en total, fueron llamados a retiro 66 oficiales. En

\footnotetext{
${ }^{31}$ Felipe Portales, op. cit., p. 230.

${ }^{32}$ Citado por Felipe Portales, op. cit., p. 231.

${ }^{33}$ Gonzalo Vial, op. cit., p. 283.
} 
1934 se agregaron otros veinte, y en 1935, veintiocho más, mientras que en los años siguientes esa cantidad fue disminuyendo. Según Vial, también fueron disminuidos otros rangos de la oficialidad, por la vía de no llenar las vacantes que se produjeran hasta el 31 de diciembre de 1933." 34

A lo dicho cabe agregar la disminución, en un diez por ciento, del presupuesto de Defensa, lo que, en el ejército, -siempre según Vial-, se tradujo en el desmantelamiento de una División, al tiempo que se reducían en dos tercios los cadetes de la Escuela Militar que pudieron acceder al grado de subtenientes ese año. A su vez, la conscripción obligatoria quedó reducida a sólo mil plazas. Todo junto a una sustancial reducción en la compra de armamentos. Paralelamente a lo señalado, se reforzó la doctrina de prescindencia política, no deliberación y acatamiento de los uniformados al poder civil.

La oligarquía, desafiando el descontento militar, aplaudió estas medidas, sobre todo desde El Diario Ilustrado. De tal modo, en fin, la amenaza militar parecía gradualmente quedar conjurada, y el ciclo iniciado en 1924, cerrado. Mientras que la Ley de Seguridad Interior del Estado y el subsecuente rol represivo de carabineros e Investigaciones permitían encarar las protestas de las clases subalternas y de la oposición.

\section{Ya depurado el ejército, la decadencia de la Milicia}

Los desenlaces arriba referidos no pudieron sino afectar a la Milicia Republicana. El objetivo perseguido por el gobierno de Alessandri al prestarle apoyo -esto es, disuadir al golpismo de la mesocracia uniformada haciendo a la vez posible llevar a cabo el descabezamiento del ejército y el establecimiento del control civil sobre el mismo- había sido cumplido. No fue entonces casualidad que, a partir de 1934, dejando gradualmente de ser útil a los grupos oligárquicos que la habían prohijado, la Milicia comenzara un lento declinar.

El declinar de la Milicia Republicana resultante de los hechos señalados, se vio acentuado con los sucesos de mayo de 1934, los que se tradujeron en su creciente aislamiento político. En ese mes se verificó una serie de atentados con bombas incendiarias, uno de los cuales afectó al domicilio de Julio Schwazenberg, autoridad máxima de la Milicia; y otro, a un cuartel de ésta en Talcahuano. Ante ello la cúpula de la entidad emitió una declaración en la cual, con nombres y apellidos, culpó del hecho a una serie de dirigentes de izquierda, gran parte de ellos parlamentarios. La Milicia Republicana -decía la mencionada declaración- , "no admitirá ser la víctima indefensa de manos cobardes y criminales. En consecuencia, notifica a usted(es) que lo(s) hará responsable personalmente de cualquier atentado de esta naturaleza que vuelva a repetirse. Y procederá a castigarlos en forma implacable. Ninguna consideración política o jurídica lo apartará de esta resolución." ${ }^{35}$

\footnotetext{
${ }^{34}$ Gonzalo Vial, op. cit., p. 281.

${ }^{35}$ Citado por Felipe Portales, op. cit., p.232.
} 
El señalado pronunciamiento generó una gran conmoción pública, configurando de inmediato un cuadro de crisis para la Milicia. Los rechazos a ella, desde todos los sectores, -con excepción de los partidos de la derecha- no se hicieron esperar, incluida la protesta formal que hiciera el presidente del Senado -Urrutia Manzano- ante el ministro del Interior. Las distintas fuerzas de la izquierda, por su parte, denunciaron la situación sosteniendo que en el país había en ciernes un Estado fascista, apoyado precisamente por la Milicia Republicana. Incluso el presidente Alessandri, -gran protector de ésta- debió marcar distancias. En efecto, declaró comprender la reacción emocional de la Milicia ante los hechos que la afectaban, pero -agregó- no era aceptable que ella pretendiera tomar la justicia en sus manos. Ante el cuadro adverso que así se generó, la cúpula miliciana, consciente del error político en que había incurrido, optó por renunciar.

Una de las consecuencias más relevantes que generó la mencionada declaración de la Milicia se vinculó al Partido Radical (PR). Este, ante los hechos relatados, ordenó a aquellos militantes suyos que formaban parte de la Milicia, que renunciaran a sus filas. Aún más, la Junta Central del partido declaró que la entidad debía ser disuelta.

Pocas semanas antes el radicalismo, -intentando que el desgaste acumulado por el gobierno de Alessandri no lo afectara- había retirado del gabinete a sus militantes, restringiendo así la base política del Ejecutivo. Alessandri, no obstante, se esforzaba por revertir tal situación, y por recuperar al PR, a lo que la descrita declaración de la Milicia no ayudaba. La Milicia, en consecuencia, para la mayoría de los actores, se fue así gradualmente convirtiendo en un elemento incómodo.

Felipe Portales sostiene que "la deserción de los radicales acentuó el tinte derechista y de clase alta de la Milicia, lo que fue minando su legitimidad y la dejó más expuesta a liderazgos autoritarios que pudieran autonomizarse en algún grado del propio Alessandri."36 Gonzalo Vial, por su parte, afirma que "el éxodo radical fue el comienzo del fin para la Milicia. Pues amén de disminuirla numéricamente, y de desorganizarla, ponía en entredicho su carácter supra partidario, la "derechizaba". En efecto, -agrega-"asumirán ahora la defensa del organismo, sólo los partidos y la prensa de este color político, especialmente $E l$ Mercurio, El Diario Ilustrado y la revista Zig-Zag." ${ }^{37}$

\subsection{El distanciamiento del núcleo oligárquico}

En el fondo, -ya descabezado el ejército y sometido a la civilidad oligárquica, y operando eficazmente la Ley de Seguridad Interior del Estado con su correspondiente represión policial sobre la protesta de las clases subalternas (signadas con el rótulo de "el comunismo")-, la Milicia Republicana no sólo se fue gradualmente haciendo innecesaria para el núcleo oligárquico, sino que, además, pasó a obstaculizar a una de las facetas de la

\footnotetext{
${ }^{36}$ Felipe Portales, op. cit., p. 233.

${ }^{37}$ Gonzalo Vial, op. cit., p. 292.
} 
estrategia que él debió implementar para mantener su poderío, a saber, la cooptación del centro, esto es, del PR.

Durante la segunda mitad de 1934 el deterioro político de la Milicia siguió su curso. En agosto el gobierno cuestionó que en Concepción, en el sepelio de uno de sus miembros, hubieran participado milicianos armados. Y para septiembre autorizó a que, en esa misma ciudad, se llevara a cabo un desfile de la Milicia, pero con la condición de que se efectuara sin armas. Análoga situación se dio, al mes siguiente, en Santiago. Aquí, el 13 de octubre, se realizó el último desfile de la Milicia. Reflejando la nueva situación política, sus fuerzas ya no pasarían frente a La Moneda y ante el presidente de la República, como ocurriera en el año anterior. Lejos de ello, la actividad partió con un mitin en el Club Hípico, para desde allí comenzar el desfile por calle Dieciocho en dirección a la Alameda torciendo aquí hacia el poniente para disolverse a la altura de Brasil.

El discurso que Julio Schwazenberg pronunciara en el Club Hípico, antes que las columnas milicianas se dirigieran hacia la Alameda, dio cuenta del aislamiento en que la entidad había quedado. "Doloroso es confesarlo -dijo allí- hemos quedado solos, aislados, dentro de la gran masa del país que no ha comprendido o no ha querido comprender....los esfuerzos de la Milicia Republicana. " Schwazenberg sobre todo se lamentó de la actitud de la oligarquía. En sus palabras, se quejó de "aquellos ..que, por su condición y su cultura, dijo- debieron entender nuestro propósito y lo desoyeron lamentablemente, causándose grave daño, pues es evidente que ellos...(serán) los más afectados por una crisis." ${ }^{38}$ Así, pues, el sector nacionalista de la Milicia, quedaba solo.

\subsection{La Milicia se repliega en su núcleo nacionalista}

Dando cuenta de lo señalado arriba, a partir de octubre de 1934 se acentuó cierto cambio de foco en las preocupaciones de la Milicia: se pasó desde un énfasis en lo militar dirigido neutralizar con las armas un golpe del ejército, a lo ideológico. Tal cosa se tradujo en el desarrollo del discurso nacionalista -que, en todo caso, existía previamente- sobre la necesidad de impulsar una reeducación del país cuyo objeto era la mejora, o revitalización, del ser nacional. Fue así como en el BIMR diversos artículos pusieron su énfasis en aquellos tópicos, tan propios de la derecha antiliberal, que versaban sobre la crisis espiritual, con su complemento, la mencionada reeducación cívica dirigida a la mejora del ser nacional, lo que, ilustrativamente, pronto empezará a vincularse a la crítica al sistema de partidos.

No es menos cierto que estos énfasis registran tempranos antecedentes. Señalemos, entre otros, el discurso que a comienzos de 1934 pronunciara Julio Schwazenberg con motivo de la creación, por parte de la Milicia, de la "Escuela de cadetes Caupolicán", la que tenía claros objetivos de corte ideológico, y cuyo sesgo conservador antiliberal es inocultable. El referido discurso de Schwazenberg representa una clara muestra de ello. Dijo entonces: "la

${ }^{38}$ Citado por Vial, op. cit., p. 294. 
crisis interna actual con sus agudísimos problemas reclama de nuestra parte una reacción decidida, inteligente y laboriosa en lo que atañe a la preparación de la infancia y de la juventud para dirigir los destinos de su patria a la altura de sus nobles antepasados...La obra es grande, (consiste en hacer posible el) renacimiento de una nueva raza para Chile." ${ }^{39}$

Los años 1935 y 1936 fueron marcando una acentuación del aislamiento de la Milicia Republicana, mientras que los énfasis de su actividad en lo político e ideológico continuaron aumentando. Así, en junio de 1935 la entidad creó el "Servicio General de Propaganda". Significativamente, el Comando en Jefe de la Milicia precisó que la propaganda del organismo debía hacerse en forma oral y escrita, ya fuera en actos culturales, cívicos y deportivos. La propaganda escrita se llevaría a cabo por medio del Boletín Miliciano, "diarios y revistas del país, volantes, cartillas y afiches, (e iría) especialmente dirigida contra el comunismo." ${ }^{40}$

En esta trayectoria la Milicia fue evidenciando claras tendencias a la autonomización política e ideológica respecto de los partidos de la derecha, que de hecho la abandonaban. En octubre de 1935, en un artículo titulado El concepto de derechas e izquierda, publicado en la revista Caupolicán, se reconoció que la Milicia se identificaba con la derecha, pero no con la derecha tradicional. El artículo, más bien, postulaba una derecha diversa, que profesara concepciones organicistas, opuestas a las visiones atomistas e individualistas de conservadores y liberales, incapaces de asumir los problemas sociales, y excluyentes de las clases subalternas. El artículo, por el contrario, decía identificarse con "una derecha que sea capaz de estructurar orgánicamente nuestro cuerpo social. Derechas sí, -agregaba el artículo-. Pero Derechas que abarquen al pueblo en su contenido histórico total. Derechas en (la) que -añadía- participen los de arriba y los de abajo sin exclusiones parcializadoras. Derechas en que se hagan presentes obreros y patrones." ${ }^{41}$ En resumen, lo que defendía el artículo era la necesidad de una derecha basada en las concepciones organicista, que eran tan propias del nacionalismo de la época, y opuesta al atomismo liberal.

\subsection{Hacia la disolución de la Milicia Republicana}

Pero, claro está, la creación de una derecha del tipo señalado -supuesto que no existiera yarequería de un órgano distinto, ya no militar, como era la Milicia, sino propiamente político. Entonces, una transformación tal se le planteó al núcleo dirigente de la entidad. Ello en el marco de su progresiva desarticulación. En cuanto a esto último, Gonzalo Vial sostiene que durante 1935 y 1936, el número de miembros de la Milicia "disminuyó, al paso que la disciplina se descomponía. Las publicaciones de la entidad reflejaban desconcierto y pugnas doctrinarias." 42

\footnotetext{
${ }^{39}$ Citado por Verónica Valdivia, op. cit., p. 107, 108.

${ }^{40}$ Citado por Verónica Valdivia, op. cit., p. 108.

${ }^{41}$ Citado por Verónica Valdivia, op. cit., p. 109.

${ }^{42}$ Gonzalo Vial, op. cit., p. 294.
} 
En la medida en que ese cuadro se generalizaba, la situación de la Milicia se hacía insostenible, sobre todo cuando uno de los objetivos de su existencia -la neutralización del golpismo de la mesocracia del ejército- parecía haber desaparecido, decayendo junto con ello el apoyo que la entidad recibiera de la oligarquía.

Los derroteros que había seguido el proceso político nacional se traducían así en resultados precisos. A saber, la disociación de los elementos que habían confluido en la Milicia. A este respecto, como hemos visto, el gobierno de Alessandri y los sectores oligárquicos habían dejado de necesitar a la entidad en la medida en que el ejército ya había sido sometido al control civil (oligárquico) y el orden institucional aparentemente se hallaba consolidado. Mientras que el partido Radical se había vuelto en su contra y retirado sus efectivos de ella, no sólo debido a que la Milicia parecía evidenciar su inocultable sesgo anti liberal, sino también en razón de que su compañía obstaculizaba el giro hacia la izquierda que, por conveniencias electorales, la colectividad empezaba a dar. En la Milicia quedaba así en pie sólo el sector nacionalista, en un creciente proceso de aislamiento. En tales circunstancias, la cúpula miliciana debió tomar la decisión final. Esto es, disolver el organismo y fundar una agrupación de derecha no liberal, de claros sesgos nacionalistas.

No es menos cierto que el proceso dirigido en esta dirección encontró una resistencia interna no menor. Una de las principales manifestaciones de ello estuvo constituida por la presentación escrita que diecinueve comandantes dirigieran a la máxima autoridad de la Milicia oponiéndose a la disolución de la misma. Los argumentos que hicieran valer eran claramente conservadores antiliberales. Subrayaban la persistencia del peligro revolucionario en el país, frente al cual la Milicia era garantía de que no prosperara.

El texto señalaba lo siguiente:"....estimamos que las circunstancias del momento no indican en modo alguno que el ambiente público esté hasta tal punto aquietado, que haya de dejarse totalmente de mano la modalidad de la Milicia como fuerza armada....". Luego la carta se refería a "las declaraciones contenidas en el último manifiesto del Block político de Izquierda...y el acuerdo adoptado hace pocos días en el Congreso del Partido Radical Socialista." Todas esas declaraciones, -agregaba la carta- al proclamar el propósito revolucionario inmediato que desgraciadamente anima a una parte de nuestros conciudadanos, demuestran la existencia, no sólo de una ideología revolucionaria, sino ya de una acción revolucionaria en pleno desenvolvimiento...(la que) no puede ser contenida, sino demostrando franca y públicamente la existencia de la fuerza defensiva contraria."43

De nada sirvieron estas consideraciones y durante los meses siguientes, el 3 de julio de 1936, el mando central de la organización emitió una orden del día que estipulaba: "declarase disuelta la Milicia Republicana y liberase de su juramento a los milicianos." ${ }^{44}$

\footnotetext{
43 Jorge de la Cuadra Poisson. La verdad de las incidencias milicianas. Talleres gráficos La Nación S.A. 1935, p.28.

${ }^{44}$ Gonzalo Vial, op. cit., p. 294.
} 
Luego de su disolución, el presidente Alessandri, a través de una carta, agradeció a la Milicia su labor de "cuatro años de mantenimiento del orden en base al respeto leal y honrado de las instituciones fundamentales de la república". En otra parte de su carta, agregaba: "se han dado las órdenes del caso para que se reciban y se reintegren a su destino las armas que fueron confiadas a ustedes y que hoy voluntariamente devuelven por elevadas razones que inspiran tal determinación." 45

A los pocos meses, -en octubre de 1936- el fundador de la Milicia, Eulogio Sánchez, creó "Acción Nacional", que debía materializar el concepto de una derecha diversa, de corte nacionalista y antiliberal.

\section{La ideología de la Milicia Republicana}

Cabe ahora referirse a la ideología de la Milicia Republicana. En relación al punto hay destacar las dos tesis más conocidas, que son la de Gonzalo Vial y la de Verónica Valdivia. El primero sostiene que la Milicia carecía de verdadera definición ideológica como no fuera la defensa del orden institucional y la restauración del espíritu cívico del país y que, en función de ello, sus filas estaban compuestas por personas que, identificándose con tales propósitos, profesaban las más diversas concepciones políticas e ideológicas. Verónica Valdivia, por su parte, cree lo contrario. A su juicio, la Milicia tenía una definición ideológica de corte nacionalista traducida en el concepto de "revitalización nacional" Tal identidad ideológica, en todo caso, a juicio de esta autora, se habría puesto del todo de manifiesto sólo cuando el ejército fuera sometido al poder civil, y cuando, en consecuencia, las preocupaciones de orden militar de la Milicia perdieran su original urgencia. Nuestro punto de vista sobre el tema se acerca más al de Valdivia, sin ser el mismo.

Para abordar el punto es previamente necesario hacerse cargo de la referencia a la pluralidad de procedencia social, política y filosófica que caracterizaba a miembros de la Milicia, -hecha por Vial- lo que supuestamente no permitiría sostener que ésta profesara una sola concepción ideológica, como no fuera la referente a la necesidad de garantizar el orden constitucional y reponer los valores cívicos en el país.

Frente a tal planteamiento debe tenerse en cuenta que, sin perjuicio de la variedad de orígenes de los miembros de la Milicia, ésta siempre respondió a la orientación exclusiva de un reducido círculo -su cúpula- el que inalterablemente permaneció siendo el mismo. Pero, lo que es más importante, hay que considerar que en ese círculo confluyeron, a su vez, elementos de diverso origen: de la oligarquía (grandes empresarios y latifundistas, personajes vinculados a los partidos conservador y liberal, y a la persona de Alessandri), profesionales prósperos y de prestigio desencantados de la dictadura de Ibáñez, a los que se agregan miembros del Partido Radical. Según argumentáramos más arriba, los objetivos de ese núcleo de composición diversa, -pero reducido- coincidían en determinados aspectos, importantes, por cierto- pero no en todo. Tal diversidad no podía dejar de reflejarse en el

${ }^{45}$ Citada en Wilfredo Mayorga, op.cit., p.514. 
plano ideológico. Diversos documentos y publicaciones de la Milicia dan testimonio de ello. En esos documentos, en efecto, junto a ideas de corte nacionalista, afloran concepciones demo liberales, (que son precisamente las que enfatiza Vial). A nuestro juicio, estas últimas correspondían a la lógica que por entonces asumiera el civilismo oligárquico el que, a los efectos de aislar y derrotar al golpismo de la mesocracia del ejército, instrumentalmente reivindicaba la racionalidad liberal. Situación análoga ocurría con los miembros de la Milicia que provenían del Partido Radical, cuyos discursos igualmente se situaban dentro de la misma racionalidad.

Pero el PR abandonó la Milicia en la primera mitad de de 1934, mientras que la oligarquía, cuando ya no la necesitó, se fue distanciando de ella. A partir de entonces dentro de la Milicia se perfiló del todo el ideologismo de los que compartían visiones nacionalistas, los que quedaron con el control ideológico de la entidad. De allí que al hablar del ideologismo de la Milicia, nos parezca pertinente identificar al mismo con sus expresiones más permanentes y elaboradas, que eran precisamente las nacionalistas.

Ahora bien, ¿cuál era la modalidad en que la Milicia profesaba ese ideologismo nacionalista? A nuestro juicio, esa modalidad consistía en la concepción cíclica de la historia, de cuño espenglereano, tomada de los textos de Alberto Edwards, Bosquejo histórico de los partidos políticos chilenos y La fronda aristocrática. Ello con las simplificaciones y adecuaciones correspondientes, acordes a los sujetos que las hacían suyas y a la coyuntura chilena de entonces.

Dicha concepción, como es sabido, en lo relacionado con la evolución de las naciones, demarca dos momentos fundamentales. A saber, el apogeo y la decadencia. Esta última conduciría a la disolución nacional, la que, no obstante, podría ser postergada -y en la versión de Edwards, incluso revertida- siempre por obra de hombres providenciales que se valdrían de la violencia salvífica para tales propósitos, quienes así reconducirían a la nación a su apogeo. Este, -el apogeo- por otra parte, se caracterizaría por la existencia de regímenes de autoridad y por la vigencia de estrictos valores morales que tendrían su centro en los intereses colectivos -los de la nación-, a cuyo servicio se consagraría la elite dirigente la cual, a su vez, -junto con su capacidad de aplicar vigorosas sanciones a quienes se desviaran de la senda recta- sería capaz de suscitar, en torno a los valores señalados, la adhesión espontánea de las clases subalternas manteniendo así la cohesión nacional.

La decadencia, en cambio, se caracterizaría por la descomposición moral del conjunto de la sociedad, incluyendo las elites; por el predominio de los egoístas intereses individuales, -de los cuales sería portador el liberalismo partitocrático-; por el triunfo del dinero y, como resultante de todo ello, por la descomposición de las instituciones, lo que se traduciría en la pérdida del vigor nacional, lo que conduciría a la disolución, la que sería acelerada por la aparición del comunismo, que no sería sino un vástago del liberalismo.

En líneas generales, es precisamente ésta la matriz conceptual que está detrás de los discursos de la Milicia Republicana (así como también de los de otros grupos de la extrema 
derecha nacionalista y antiliberal de la época). Distinto es que sus emisores estuvieran más o menos conscientes de ello y que tales discursos no siempre llegaran a explicitar todos los componentes de tal matriz. En la práctica ocurría que ni los líderes de la Milicia Republicana normalmente sabían que eran esencialmente espenglereanos (en la versión de Edwards), ni sus discursos explicitaban siempre el conjunto de la correspondiente matriz conceptual, sino, muchas veces, sólo fragmentos de ella, dejando el resto implícito. En otros casos, sin embargo, con bastante claridad esa matriz aparece completa.

De aquí se deduce que el procedimiento para estudiar el ideologismo de la Milicia Republicana debiera consistir en identificar aquellos de sus discursos que muestran con más claridad estar construidos en base a la señalada matriz conceptual espenglereana en la versión de Alberto Edwards, para luego visualizar cómo otros de sus discursos representan aspectos parciales de la misma. A continuación procederemos según ese criterio.

El texto de Teodoberto Álvarez, Por el buen orden social, que el 15 de enero de 1934 fuera publicado en el Boletín Informativo de la Milicia Republicana, parece representar, con sus correspondientes corolarios políticos, una buena versión de la referida concepción cíclica, aplicada a la historia de Chile. La interpretación que el texto hace de ésta, en efecto, esencialmente gira en torno a la dialéctica entre apogeo y decadencia, aunque no se vale estos conceptos. Según el texto, el apogeo, -los "viejos buenos tiempos" según su terminología-, se habría verificado durante la llamada república autoritaria, mientras que la decadencia se había desplegado desde finales del siglo XIX en adelante, teniendo, en lo político, su expresión máxima en el parlamentarismo y en la anarquía post 1924, y en lo económico, en la entrega de las riquezas naturales al extranjero. Ambos momentos, a su vez, configurarían la dualidad entre "autoridad fuerte", propia del apogeo, y la autoridad débil, que caracterizaría a la decadencia, mientras que en lo ideológico cada ciclo perfilaría la oposición entre la vigencia de elevados valores nacionales, que giraban en torno a la idea de honestidad, -que sería lo propio del apogeo-, versus la corrupción generalizada que identificaría a la decadencia. Veamos cómo este esquema se verifica en el referido texto de Teodoberto Álvarez.

Si analizamos serenamente la historia de nuestra patria, desde la independencia hasta ahora, -se señala en él- veremos fácilmente los mayores contrastes en su evolución como país independiente y soberano; en vez de una línea de progreso indefinido, observaremos otra llena de zig-zags, de quebraduras y rupturas que han amenazado hasta la existencia misma de la República". ${ }^{46} \mathrm{Y}$, en referencia a esos contrastes, agrega: "llegamos a merecer, en el pasado, el honroso calificativo de "ingleses de Sudamérica"; pero hoy, vergüenza da decirlo, vivimos confundidos en el revuelto montón de países habitados por nativos, por aborígenes, por indios sudamericanos, como dicen despectivamente los hombres de otros pueblos. ${ }^{47}$

\footnotetext{
${ }^{46}$ Teodoberto Álvarez, Por el buen orden social, Boletín Informativo de la Milicia Republicana, Año 1, $\mathrm{N}^{\circ} 12$, 15 de enero de 1934.p.5

${ }^{47}$ Teodoberto Álvarez, p.5
} 
Bajo estos supuestos, Álvarez atribuye a "los organizadores de nuestra nación".. "un profundo espíritu nacionalista, que habría operado "hasta mediados del siglo pasado", espíritu al que asocia a prácticas de fuerte autoridad. Ilustrando esta idea, agrega que "en aquellos buenos viejos tiempos la administración pública chilena tenía fama de ser una de las primeras del mundo por (su) severidad.....Los intendentes, los gobernadores, los subdelegados y los inspectores (o sea, los brazos ejecutores del gobierno).-añade- ....debían velar por el orden público, haciendo arrestar y poner a la disposición de la justicia a todos los que atentaran contra el orden social.." ${ }^{48}$ Tal sería, a juicio de Álvarez, el rasgo definitorio de los "buenos viejos tiempos" en el plano político. O sea, el autoritarismo

En el plano económico, esos "viejos buenos tiempos, -es decir, el apogeo-, se habrían caracterizado porque "las minas de oro, plata, de cobre y de carbón eran explotadas por chilenos y con capitales chilenos, (y) nuestros trigos y nuestras harinas llegaban hasta San Francisco de California." ${ }^{49}$ Mientras que en lo moral, -dice Álvarez- en esos tiempos "la palabra de un caballero valía más que una escritura pública y hoy -añade- ni con diez escrituras públicas se suele asegurar la palabra de un caballero." ${ }^{10}$

La decadencia, a juicio de Álvarez, habría empezado pronto. Su punto de inflexión habría residido en el desmontaje del autoritarismo del régimen político. "Las leyes de régimen interior de 1885, la de comuna autónoma de 1891 y la revolución de ese año, -sostienetrastornaron definitivamente la antigua estructura política y social del país, convirtieron al Presidente de la República en un verdadero rey viga, sin autoridad ni medios para defender la buena marcha de los servicios... de modo que, momento a momento, la anarquía se fue convirtiendo en sistema de gobierno y la voluntad de cualquier diputado o senador omnipotente bastó para derribar los ministerios y para impedir el despacho de cualquiera medida legislativa que no fuera de su agrado." El aparato del Estado, entonces, "en lugar de servir a la sociedad...apareció como el peor enemigo del progreso nacional..." "Después del 91, -añade Álvarez- cualquier bribón podía ser empleado público y, mientras contara con el apoyo de un diputado o de un senador, podía reírse de todo el mundo."

Mientras que en lo económico -añade- "fuimos abandonando el sano amor por lo nacional para preferir torpemente todo lo extranjero (y) poco a poco fuimos entregando la explotación de nuestras riquezas naturales al capital extranjero..." 52 Al tiempo que en lo moral, -dice- "después que se suprimió la prisión por deudas, la fuerza de las viejas tradiciones hizo que la anterior moralidad persistiera por algún tiempo; pero poco a poco, insensiblemente, fuimos perdiendo el respeto a la palabra empeñada." A partir de entonces, sostiene "manifestaciones de descomposición social, como el abandono de los hijos, la

\footnotetext{
${ }^{48}$ Teodoberto Álvarez, p.5

${ }^{49}$ Teodoberto Álvarez, p. 7.

50 Teodoberto Álvarez, p.5

${ }^{51}$ Teodoberto Álvarez, op.cit. p.6.

52 Teodoberto Álvarez, op. cit., p.7.
} 
deslealtad y la calumnia, sentaron plaza en nuestra tierra, en lugar de la austeridad de otros tiempos.."

Álvarez procede luego a explicar las razones del paso desde el apogeo a la decadencia. A su juicio la causa de ello se encontraría en la ideología. Particularmente en la imposición de las ideas liberales, tanto en lo económico como en lo político. Ese cambio, sostiene, "fue producido principalmente por la acción de un profesor francés de Economía Política (Corcelle Seneuil) contratado por el gobierno de don Manuel Montt". "Este profesor agrega- enseñó en Economía un libre cambio absoluto y en política un liberalismo enfermizo." Como producto de la imposición de las ideas liberales, dice Álvarez, "se derogaron las viejas leyes nacionalistas $\mathrm{y}$, a fines del siglo, se modificaron las leyes políticas y administrativas, quitando los antiguos controles y dejando al país sin defensa contra la anarquía interior y contra el avance de los imperialismos económicos en el exterior." ${ }^{54}$

En resumen, en la hermenéutica de Álvarez, la causa de todos los males del país radicaría en el desplazamiento del nacionalismo por el liberalismo. Tal cambio ideológico, sostiene, habría producido la crisis nacional, con su correspondiente anarquía, incluyendo "una crisis de hombres dirigentes." La conclusión de Álvarez es clara: "si queremos salir del desorden en que nos debatimos, -sostiene- debemos modificar nuestras tendencias ideológicas". ${ }^{55}$ Es decir, se requeriría renunciar al liberalismo y retornar al antiguo nacionalismo autoritario, bajo cuya dirección ideológica se produjera el apogeo del país.

Análogo esquema sigue la alocución que con el título de "A los compañeros de la Milicia Republicana", pronunciara en noviembre de 1932 uno de los miembros más importantes de la cúpula de la entidad: Jorge de la Cuadra Poisson.

Como se verá, en dicha alocución De la Cuadra llegó incluso a explicitar su adhesión a la concepción cíclica de la historia. En esa línea, comparó el desorden y la anarquía que creía ver en el presente, -con su secuela de intervenciones militares-, con lo que habría existido antes de 1830.Al respecto señaló: "cien años atrás, el panorama político y social de Chile, era de todo punto semejante al que hemos vivido desde 1924. La intervención del Ejército en la cosa pública, los frecuentes cuartelazos o levantamientos de tropas, las revoluciones hechas con el solo propósito de aumentarse los sueldos o de conservar las granjerías conseguidas, las traiciones convertidas en métodos políticos, la impunidad absoluta de los conspiradores y revoltosos, el aplastamiento total de los caracteres, todo, todo era análogo al triste espectáculo que hemos visto desarrollarse ante nuestros ojos en el último decenio." 56

\footnotetext{
${ }^{53}$ Teodoberto Álvarez, op. cit., p.6.

54 Teodoberto Álvarez, p.7.

55 Teodoberto Álvarez, p.7.

${ }^{56}$ Jorge de la Cuadra Poisson, "A los compañeros de la Milicia Republicana", noviembre de 1932, p.16.
} 
Luego De la Cuadra llamó a no desanimarse ante esta constatación, precisamente en razón de que el caos que describe representaría sólo una fase del ciclo histórico, fase que podría ser revertida mediante la enérgica acción de personalidades excepcionales, normalmente conceptuadas como "salvadoras de la patria."

"La acción tesonera, el deseo inquebrantable de vencer las dificultades y de salvar la patria con que afrontaron el Gobierno los recios estadistas de aquel entonces, -sostiene De la Cuadra- fue bastante para dar tranquilidad al país, impulso al comercio, solidez a las instituciones, prestigio a la República y confianza a todos." ${ }^{57}$ Dicho de otra manera, habría sido la enérgica acción de los salvadores de la patria (Portales y los estanqueros, agreguemos de nuestra parte), los que, superando la anarquía previa, abrieron paso al apogeo del país.

De la Cuadra traslada ese proceso a los años treinta del siglo XX. En efecto, sostiene que la decadencia en la que entonces el país se debatía, en la medida en que era parte de una historia cíclica, sería igualmente revertida. De allí que agregara: "no hay, pues, razón alguna para desesperar. Lejos de ello -añade- si es verdad que la historia se repite por ciclos, todo haría esperar en la proximidad de un estado de cosas que hiciera posible el desenvolvimiento ordenado y fecundo de las mejores energías nacionales." ${ }^{58}$ Esto es, sería de esperar un estado que dejaría atrás la decadencia en curso y donde el país se encaminaría hacia el apogeo.

Claro que la superación de la fase decadente del ciclo histórico que reconduciría al país a su fase de apogeo, no operaría de manera espontánea. Muy por el contrario, dependería de la existencia de un grupo de hombres enérgicos, con voluntad, de fuerte conformación moral, capaces de tomar conscientemente la decisión salvadora. Para De la Cuadra, ese grupo se encarnaría en la Milicia Republicana.

De aquí se deducía que el esfuerzo de la Milicia no se limitaría a poner fin a la recurrencia del golpismo de los militares y restaurar la constitucionalidad, como a primera vista pudiera parecer, y como lo sostiene Vial. Según la lectura de De la Cuadra, detener al golpismo (mesocrático) en curso, en realidad, era para la Milicia sólo un fin intermedio cuya consecución debía permitir avanzar al fin último, que era retornar a la fase de apogeo del ciclo de la historia nacional. Ello, como se dijo, a través de la acción enérgica de un grupo decidido y de solvencia moral. Esa es la lógica del planteamiento de De la Cuadra.

El decisionismo salvífico implícito en los planteamientos de esta autor, pone de manifiesto, por otra parte, una faceta adicional, de particular importancia. A saber, la voluntad de utilizar la violencia armada para conseguir los fines propuestos, elemento que en el arriba referido discurso de Álvarez, no figura, pero que, obviamente, es inherente a la Milicia Republicana. No en vano esta era una organización político militar.

\footnotetext{
${ }^{57}$ Jorge de la Cuadra Poisson, op. cit., p.16.

${ }^{58}$ Jorge de la Cuadra Poisson, op. cit., p.16
} 
La mencionada faceta decía relación con una voluntad que, rechazando compromisos y negociaciones con "el enemigo", decidía, al modo schmittiano, estar preparada para emprender las eventuales acciones armadas decisivas orientadas a revertir la decadencia.

Sobre el punto De la Cuadra señala lo siguiente: "cuando un país no encuentra un camino que sea la digna continuación de su historia, no sigue cualquiera, sino que se abre uno". "Esto -agrega- equivale a decir que es necesario coger las armas, que es imperioso batirse antes que seguir cayendo". 59

De este modo, para De la Cuadra, la decisión de usar las armas (por parte de la Milicia Republicana) era una respuesta ante la decadencia, esto es, un intento por detenerla y revertirla. Y, por tanto, un recurso para ponerle fin y retornar a la fase de apogeo del ciclo histórico.

Es desde tal óptica decisionista, -tan propia de la extrema derecha-, que De la Cuadra sometió a crítica a la ideología que aceptaba el compromiso con los supuestos forjadores de la decadencia. "Los pueblos no pueden vivir eternamente de componendas y transacciones, sostiene, en efecto. Hay problemas que exigen resolverse con las armas en la mano; y a éstos hay que darles la solución adecuada y no otra."60

Pero el uso de las armas, para no devenir en un elemento más de la anarquía y del caos propio de la decadencia, -y para servir al fin de retornar al apogeo del ciclo histórico nacional-, debía acompañarse del elemento ético. La violencia armada debía, en efecto, ser un instrumento utilizado no por cualquiera, sino por una elite caracterizada por su fuerte complexión moral, cuestión indispensable para refundar al país. De allí que De la Cuadra señalara que "la Milicia Republicana, inspirada en sus sanos principios, deberá crear una fuerza moral que sacuda en lo más íntimo la vida ciudadana, que reforme y rehaga el país a semejanza del ideal que soñaron nuestros mayores, cuando echaron a andar resueltamente la República hacia adelante, y le mostraron con índice seguro el camino del porvenir." 61

De este modo, en la versión de De la Cuadra, -rechazando la cultura de compromiso y asumiendo la eventual necesidad de la violencia armada, siempre sobre una sólida base moral refundadora- la misión de la Milicia Republicana consistiría en rehacer el país para que éste retornara a la fase de apogeo que cimentaran "nuestros mayores", quienes, a su juicio, "echaron a andar resueltamente a la república."

Es en dicho marco que hay que visualizar la insistencia con que los textos milicianos se refieren a la necesidad de reconstruir moralmente al país y la definición que constantemente hicieran de la Milicia como una fuerza no sólo militar, sino también ética. En resumen, el

\footnotetext{
${ }^{59}$ Jorge de la Cuadra Poisson, op. cit., p.20

${ }^{60}$ Jorge de la Cuadra Poisson, op. cit., p.20

${ }^{61}$ Jorge de la Cuadra Poisson, op. cit., p.20.
} 
planteamiento de De la Cuadra, -quien explícitamente profesa la concepción cíclica de la historia nacional-, postula dos componentes fundamentales para volver a la etapa de apogeo del ciclo de la historia nacional: las armas y la transformación de la moral, lo que, por lo demás, implicaba superar la cultura de transacciones.

Por cierto, nada de esto es ideológicamente liberal. Como hemos visto, se trata de planteamientos ubicados más bien dentro de la lógica nacionalista. Más aún cuando, en la ideología de la derecha dura, el apogeo que postula la concepción cíclica de la historia nacional se vincula al autoritarismo.

El texto de Silva Vildósola, La milicia educa a una generación, aparecido el 15 de septiembre de 1933 en el Boletín Informativo de la entidad (BIMR), si bien es menos explícito que el de De la Cuadra en cuanto a la concepción cíclica de la historia nacional, no deja de insinuar su impronta.

Así, al modo de dicha concepción, el texto traza el contraste entre un presente decadente y un pasado edificante. "Cuando Chile vivía en orden y en el imperio pleno del derecho, sostiene el artículo- no se necesitaba la fuerza para que se cumplieran la Constitución y las leyes. Bastaba con la ley no escrita que está grabada en las conciencias." ${ }^{62} \mathrm{Y}$, más adelante, añadía: "existían en Chile organizaciones que a la vez velaban por el mantenimiento de la vida normal y educaban a los ciudadanos en ella: eran los partidos políticos disciplinados, con ideales, con principios, con moralidad. La disolución de esos partidos -añade- hizo posible y dio pretexto a las subversiones.", ${ }^{63}$ que serían expresión de la decadencia del presente.

Bajo estos supuestos, la Milicia Republicana figura en el texto de Silva como una reacción en contra de la decadencia que invadiría al país. "Al desencanto lógicamente producido por los sucesos de los últimos años, y la descomposición política que les precedió, -dice- la Milicia opone el entusiasmo contagioso de una gran causa nacional." 64

La referida causa nacional, implícitamente consistía en la superación de la decadencia. Tal cosa mediante una restauración de la moral y la revitalización del espíritu nacional. El artículo, en otra parte, en tal sentido, señala que "a la negación de la idea de Patria, (propia de la decadencia), (la Milicia) opondría "una voluntad resuelta de dar la vida por la tranquilidad, la honra y la dignidad de Chile." 65

Análoga lógica anima al ya citado discurso que Julio Schwazenberg pronunciara con motivos de la creación de la escuela Caupolicán, cuando sostuviera que ante "la crisis

\footnotetext{
${ }^{62}$ Carlos Silva Vildósola, La milicia educa a una generación, Boletín Informativo de la Milicia Republicana, Año 1, $\mathrm{N}^{\circ}$ 4, 15 de septiembre de 1933, p.5.

63 Silva Vildósola, op. cit., p.5.

${ }^{64}$ Silva Vildósola, op. cit., p.5.

${ }^{65}$ Silva Vildósola, op. cit., p.6.
} 
interna actual con sus agudísimos problemas", la Milicia representaba "una reacción decidida, inteligente y laboriosa en lo que atañe a la preparación de la infancia y de la juventud para dirigir los destinos de su patria a la altura de sus nobles antepasados..."La obra es grande", -agregó- y consistiría en hacer posible el "renacimiento de una nueva raza para Chile." ${ }^{66}$ El renacimiento de una nueva raza para Chile venía a ser, en el discurso de Schwazenberg, un componente de la superación de lo que denomina como "la crisis interna actual con sus agudísimos problemas" (la decadencia). Esa raza, en fin, debía conducir a la "patria a la altura de sus nobles antepasados" (es decir, al apogeo). Y así sucesivamente. Los textos de los líderes de la Milicia republicana expresan, de una u otra forma, la lógica descrita.

La señalada concepción cíclica de la historia nacional viene, por otra parte, acompañada, en los discursos de la Milicia, de abundantes conceptos conservadores, como los de familia, orden, autoridad, anticomunismo, etc. En cuanto a esto último, la Declaración de Principios de la Milicia, como viéramos, sostenía que ella combatiría "toda tiranía, ya sea esta comunista, civil o militar." En el Juramento Miliciano se señalaba lo mismo. Los milicianos, según dicho texto, juraban "combatir por cualquier medio toda tiranía, ya sea comunista, civil o militar." Y en el panfleto lanzado desde un avión sobre Santiago el 7 de mayo de 1933 mientras 14.000 milicianos desfilaban frente a La Moneda, se afirmaba que la Milicia iba "contra el caudillo sin escrúpulo y contra el comunista sin patria. " etc. Lo señalado pone en evidencia que para la Milicia Republicana las expresiones más claras de la descomposición nacional que a la fecha se viviría, -expresiones de la decadencia- eran precisamente la acción de la mesocracia militar (los "caudillos sin escrúpulos") y el alza del Partido Comunista, (a lo que se unía la descomposición moral del país, en buena parte inducida desde Moscú, según se señalara en un artículo del BIMR citado arriba. De allí la actitud contraria de la Milicia frente a unos y otros. A ellos oponía las ideas tradicionales de patria, familia, orden, moralidad. Así, la Declaración de Principios de la entidad sostenía que ésta buscaba enaltecer "en el alma de todos, los sentimientos supremos de Patria, Hogar y Trabajo", valores tradicionales que junto a la estabilidad institucional, serían propios del apogeo al que habría que retornar.

A lo dicho agreguemos la creciente reticencia que se fue desarrollando dentro de la Milicia frente a los partidos políticos tradicionales, y la atracción verificada en su seno por las organizaciones de tipo organicista afines al nacionalismo. Tal es lo que, entre otros, ilustra el arriba citado texto El concepto de derechas e Izquierdas, que fuera publicado en la revista Caupolicán en octubre de 1935. En breve, se podría sostener que la Milicia Republicana distó mucho de ser una entidad sin ideología. Según hemos visto, la ideología que ella profesaba era de un notorio carácter nacionalista. Articulada en torno a una concepción cíclica de la historia de Chile que se materializaba en la dialéctica de apogeo y decadencia, conllevaba, adicionalmente, una voluntad decisionista que se plasmaba en la construcción de un instrumento -que era la propia Milicia- capaz de ejercer una eventual

${ }^{66}$ Citado por Verónica Valdivia, op. cit., p. 107, 108. 
violencia armada en contra de los factores de la decadencia (el golpismo militar y el comunismo), apuntando con ello a reversión del ciclo. Propuesta que, en fin, en cuanto a los elementos subjetivos, suponía la "revitalización nacional", esto es, la recuperación de la moralidad y la voluntad de la nación.

\section{Conclusiones}

Las consideraciones que hemos hecho a lo largo de estas páginas nos permiten concluir en que la Milicia Republicana, -ejército de civiles creado al margen de la Constitución y la ley- más allá de su apariencia, distó mucho de ser un organismo homogéneo, ni en sus componentes, ni en sus fines. Dejando de lado a su base militarizada (tropa y baja oficialidad), se puede decir que en ella confluyeron tres elementos principales, que fueron:1) segmentos ligados a la oligarquía; 2) grupos de profesionales exitosos caracterizados por un ideologismo nacionalista y antiliberal; y 3) sectores del Partido Radical.

De esta diversidad emanaron objetivos compartidos por todos, pero también perspectivas estratégicas distintas. Los objetivos compartidos consistían en poner fin al intervencionismo en política de la mesocracia del ejército, de tradición ibañista. La diferencia de perspectiva estratégica se expresaba en que para los sectores de la Milicia identificados con la oligarquía, el fin del intervencionismo militar, y el consiguiente sometimiento del ejército a la civilidad, sería funcional a la reconstitución de la dominación oligárquica de acuerdo a las condiciones de la década de los treinta (presidencialismo, Constitución de 1925, etc.). Mientras que para el Partido Radical, -colectividad altamente pragmática- ese sometimiento era la condición para la restitución de una normalidad institucional que era la precondición para su inserción en las altas esferas del Estado, satisfaciendo con ello sus intereses corporativos y el de sus clientelas, cosa que podría ser lograda en alianza con los partidos de la oligarquía, o con otras fuerzas, como ocurrirá más adelante. Para un tercer sector de la Milicia, que definimos como nacionalista, -el que en gran parte se hallaba vinculado ciertos profesionales de prestigio que tuvieron una participación muy importante en la conformación de la entidad-, el objetivo de la Milicia era revertir lo que consideraban era la decadencia nacional, a la que terminaron asociando a los vicios del sistema (liberal) de partidos y con la emergencia del comunismo.

Cuando el objetivo compartido por todos los señalados segmentos fue conseguido, esto es, el sometimiento del ejército a la civilidad (oligárquica), la Milicia entró en crisis en la medida que perdió el apoyo del Partido Radical y del núcleo oligárquico. Entonces persistieron en ella sus sectores nacionalistas, con sus tesis sobre la reversión de la decadencia y la revitalización nacional, quienes, privados de los apoyos anteriores,

finalmente decidieron transformarse en un movimiento político de carácter explícitamente nacionalista, que fue Acción Nacional. 
En cuanto a sus definiciones ideológicas, la diversidad de los elementos que confluyeran en la Milicia Republicana, se tradujo en que, al menos temporalmente, sus discursos fueron un tanto sincréticos, coexistiendo elementos demo liberales con nacionalistas. Pero, a partir de 1934, cuando el PR la abandone y la oligarquía se distancie de ella, emergerá con fuerza en su seno el discurso nacionalista articulado en base a la concepción espengleriana, (según la versión de Edwards), con sus temáticas de la decadencia y su reversión mediante un decisionismo armado que apuntaba a la instauración de gobiernos autoritarios.

\section{Bibliografía}

-Verónica Valdivia: Las Milicias Republicanas. Los civiles en armas, 1932-1936. Centro de Investigaciones Barros Arana, Santiago, 1992.

-Gonzalo Vial: Historia de Chile. Volumen V. De la República Socialista al Frente Popular (19311938), Ed. Zig-Zag, Santiago, 2001.

-Luis Corvalán Marquez, Nacionalismo y autoritarismo durante el siglo XX en Chile. Los orígenes, 1903-1931, Ediciones de la Universidad Católica Raúl Silva Henríquez, Santiago, 2009.

-Sofía Correa, Con las riendas del poder. La derecha chilena en el siglo XX. Editorial Sudamericana, Santiago,2004.

- Wilfredo Mayorga, "Crónicas Políticas de Wilfredo Mayorga, del "Cielito lindo" a la Patria joven," Fuentes para la Historia de la República, Volumen XI, Recopilación, Rafael Sagredo, DIBAM, RIL y Centro de Investigaciones Barros Arana, Santiago, 1998.

-Felipe Portales, Los mitos de la democracia chilena, V.II, Ed. Catalonia, Santiago, 2010.

-Carlos Maldonado, La Milicia Republicana: historia de un ejército civil en Chile, 19321936.FLACSO.

- Jorge de la Cuadra Poisson. La verdad de las incidencias milicianas. Talleres Gráficos La Nación S.A. 1935.

- Teodoberto Álvarez, Por el buen orden social, Boletín Informativo de la Milicia Republicana, Año 1, $N^{\circ} 12,15$ de enero de 1934.

- Jorge de la Cuadra Poisson, "A los compañeros de la Milicia Republicana", noviembre de 1932.

- Silva Vildósola, La milicia educa a una generación, Boletín de la Milicia Republicana, 15 de septiembre de 1933.

-Declaración de principios de la Milicia Republicana, Impr. Universo, Santiago, 1935.

-Juramento Miliciano. En : La Milicia Republicana : Álbum conmemorativo de su presentación pública, Santiago de Chile, 7 de mayo de 1933. Santiago, Imp. Universitaria 1933, pp 2. 